\title{
BIRDS AND FLOWERS
} ABOUT

\section{CONCORD, NEW HAMPSHIRE}

\author{
FRANCES M. ABBOTT
}




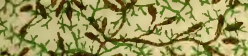

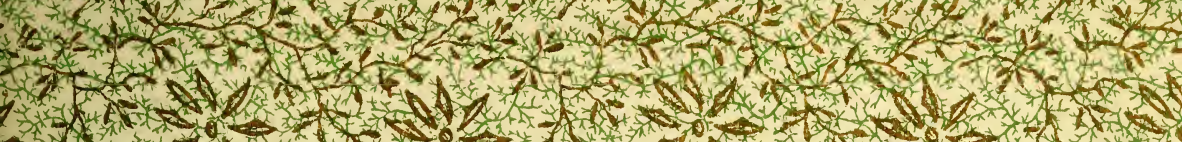

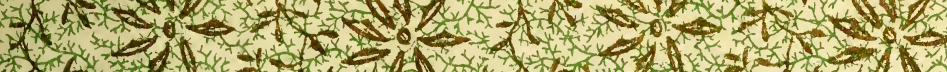

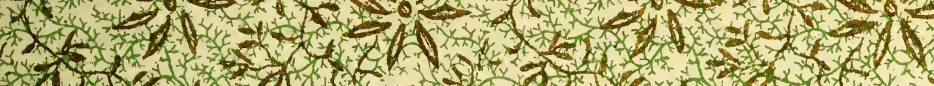
1.7.

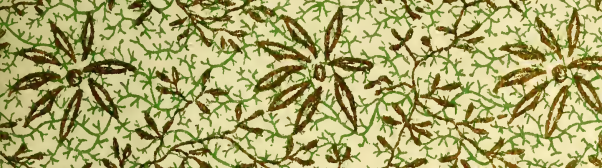

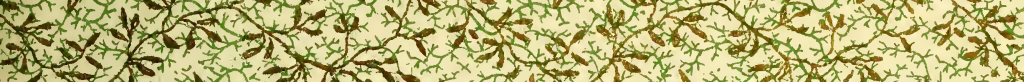

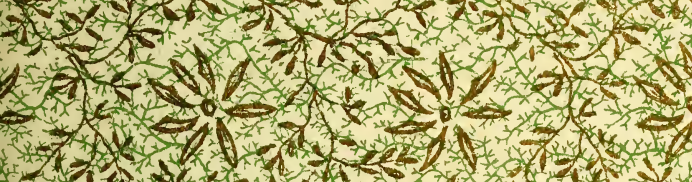
1. 1. 1.

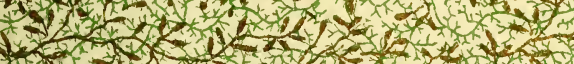

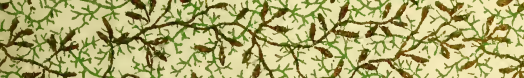
(1) , t... $=1,1+1,1+2$

(1), $\frac{1}{2}+0$

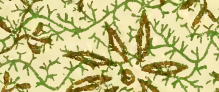

. 放

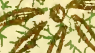
$7+1-1,1-1$

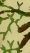

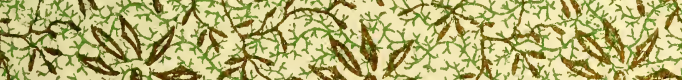
3.

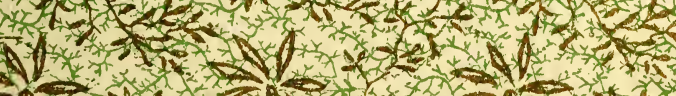
(1) (1, U 10 $n+1$ L 
$q e$ 


\section{BIRDS AND FLOWERS} ABOUT

\section{CONCORD, NEW HAMPSHIRE}

\section{By \\ FRANCES M. ABBOTT}

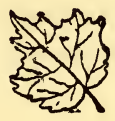

"The partial wood-gods overpaid my love, And granted me the freedom of their state,

And, chiefest prize, found I true liberty,

The home of homes plain-dealing Nature gave."

Emerson.

CONCORD, NEW HAMPSHIRE RUMFORD PRINTING COMPANY

Nineteen Hundred and Six 
Copyright 1906, BY MISS FRANCES M. ABBOTT All rights reserved 
N4A 13

RB

$S I$

TO THE CHILDREN OF CONCORD

FROM ONE

WHO LOVES HER NATIVE TOWN. 


\section{CONTENTS.}

Prologue

Hints for Beginners . . . . . xiii

Books for Nature-Lovers . . . . xvi

Local Names in This Book . . . . $\quad$ xx

The First Robin . $\quad$. $\quad$. $\quad$. $\quad$. $\quad$. $\quad$. 1

A Feathered Prince.$\quad$. $\quad . \quad$. $\quad$. $\quad . \quad 5$

Birds After the Snow Storm . $\quad$. $\quad$. 8

A Warbler Shower $\quad$. $\quad . \quad$. $\quad . \quad 12$

The Spring Rush . $\quad$. $\quad$. $\quad$. $\quad$. $\quad 16$

The Hermit of the Wood . . . . . . 21

The Merry Month of May . . . . . $\quad$ - 26

Two Rare Warblers $\quad . \quad$. $\quad . \quad$. $\quad . \quad 30$

Jewels in the Street . . . . . . . 33

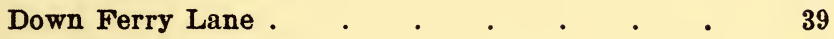

Our Winter Visitors . . . . . . . . 49

Shrike vs. Sparrow $\quad$. $\quad$. $\quad$. $\quad$. $\quad$ • $\quad$ • 55

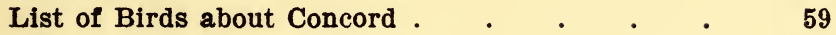

Alphabetical Index of Birds . . . . . 70

Characteristic Flowers of Concord . . . . $\quad 75$

The Royal Family of Orchids . . . . $\quad$. 87

The Seed Harvest of Rattlesnake Hill . . $\quad 97$

List of Flowers About Concord . . . . 103

Alphabetical Index of Flowers . . . . . 121 


\section{PROLOGUE.}

Many years ago a little girl lived in Concord, who loved everything out of doors - the air, the clouds, the hills, the running water, the birds and the flowers. She especially loved the birds, because they were alive. She wanted to know their names, but nobody could tell her. Her people did not know; her teachers did not know; she never found anybody who did know. Nothing of that sort was ever taught in the schools, and yet they were always telling how good the schools were in those days. She used sometimes to wonder if it were wicked to want to know about things that she saw out-doors, because everything of that sort was religiously kept out of the schools.

She learned to read and spell up at the "Little Brick," and that knowledge has always stood by her; but her days at the old Merrimack Grammar were spent over Walton's Card (adding up figures that meant nothing to get results that nobody wanted to know); partial payments; Quackenbos's Grammar; and the geography of Central Africa (that represented all the world outside of Concord). She has never met a partial payment in real life (of the kind the arithmetic taught); Quackenbos's Grammar has become as 
obsolete as the quack who wrote it; and as for Central Africa, the world is changing so fast that she is learning her geography anew every day. Three things, however, remain from Grammar School days: the knowledge of Colburn's Arithmetic (the best mental discipline ever invented), the strong meat of Sargent's and Hilliard's Readers, and the Constitution of the United States committed to memory. Her literary sense at once singled out that document as being the one vital fact amid all the wearisome details in a book written by a man who did not know how to make history readable.

In the High School she tumbled into the classics, ancient and modern, likewise Algebra and other fascinating sciences. She began to gain an outlook. Everything was interesting, and nothing has been forgotten; but even here she did not get what she wanted. When she was graduated from the High School she did not know a bluebird from a barn swallow; and as for Botany, though she had analyzed the required number of plants, her chief recollection was of achenia and cotyledons, and whether something or other was perigynous or hypogynous. She could not tell the name of the pink knot-weed that grew in the back yard, and all the flowers that her friends cared for 
were cultivated things in gardens, petunias, mullein pinks, candytuft and the like.

Presently she went to college and was confronted by heights and depths of learning; but still there was something lacking. She studied Zoölogy, and found that birds were classified by their toes. That disgusted her with the whole subject. She cared no more about the anatomy of birds than she did about the skeletons of her friends. What she wanted was to associate with them as living beings; to know them as "folks." The creature that most impressed her in Zoölogy was the amphioxus; but she has never met an amphioxus in real life any more than she has met an asymptote, another uncanny thing that she was studying about under another erudite professor. Of course she learned heaps and heaps of things at Vassar; among them that a north room is not only cooler in winter, but warmer in summer than a south room; also, that spring-beauties grow in the neighborhood of the Hudson and Mayflowers do not, while the reverse is true of Concord; also, that fried oysters and olives are good to eat at midnight or any other hour. She also got a mental discipline that reconstructed the world for her, but she had no time to live with the birds and flowers. 
It was not till 1885 when she crossed Lake Winnepesaukee with the Appalachian Mountain Club and climbed Red Hill that she at last found the information that she wanted. Here was a company that knew everything. They had lived the out-door life. Not a mountain hove in sight that they could not name; each island was familiar. Everything in the heavens above or the waters underneath was to them as an open book. They wore indestructible clothes and possessed gay dispositions, unaffected alike by sun, wind or rain. They knew everything and could do everything, and with them life was worth living. It was with the humble hope of introducing something of the spirit of these Boston Aborigines into Concord that the writer helped found the Wild Flower Club in 1896. For ten years the members have taken weekly tramps from the middle of April till the first of October. They have learned to know hundreds of flowers and scores of birds in that time, have explored every nook and corner in the township, and have gained a spiritual satisfaction from Nature such as Wordsworth and Emerson knew.

This little publication is an endeavor to bring before other people, especially the children, some of the joy that comes from knowing the common things that we 
see around us. The fact that the book is intensely local constitutes whatever merit it may have. There is nothing herein described that any Concord citizen with an opera-glass cannot see by taking a little pains. Perhaps exception should be made of the game-birds of which such a generous list has been furnished by the sportsmen. These birds are all shot on our meadows, and their stuffed bodies in local cabinets furnish ocular demonstration of their presence here; but many of them, especially the sea-fowl, are rare, and are found about Concord only when blown in after a storm.

The writer is emboldened to put forth this little book by the thought that, imperfect as it is, a like publication would have been a treasure to her when she was young. With the hope that it may be a foundation for better observers to build upon, it is laid before a circle of indulgent friends. The following lines, written by Miss Sarah F. Sanborn, the accomplished president of the Wild Flower Club, admirably express the spirit that makes all Nature-lovers kin. The verses were written some years ago when White Park was just emerging from White's Swamp, and the place was still a haunt of the wild flowers. 
"Have you been

On a lark to the park?

Have you seen

The fern-fronds first

From the brown earth burst?

Have you eyes

To surprise

The green speckled frog

In his native bog?

Or a will to venture

The gentle censure

Of Robin the sweet

In his green retreat?

Or feet

To meet

The rill

That leaps a-down the hill?

Have you a heart

To ease the smart,

The ache, the strain

of nerve and brain

With herbs the field

Doth yield?

Then here is my hand

At your command.

Good comrades we

Shall be."

Frances M. Abbott.

June 15, 1906. 


\section{HINTS FOR BEGINNERS.}

The writer is often asked how one can get started in the study of birds. It is comparatively easy to know the flowers. Any of the popular illustrated books, like Mrs. Dana's, in which the flowers are classified by color and season, furnish all the information desired; and with the flower in your hand, to find its counterpart in the book is as easy as matching ribbon. But with birds, it is another matter. They will not stay still, and they all look alike to the novice. How can an amateur tell whether the bird has a striped crown or yellow wing-bars or white blotches on its outer tail-feathers or a black line through its eye when all that is seen is a confused blur as the creature flies past?

It is impossible to do anything till one's eyes are trained. Begin with the robin. Of course we all recognize the robin; but how many know him? Ask anyone, not a bird student, about his length, and you will get answers varying all the way from six to sixteen inches. The robin's length is ten inches, and he is the standard measuring-rod. All birds over that length are considered large; and those less in size, the 
majority of our song-birds, are called small. The sparrows average six and a half inches, and the warblers five and one half inches. The thrushes, bluebirds, wax-wings or cedar-birds and the orioles are from seven to eight inches. The grosbeaks are eight and a fraction and the catbirds are nearly nine inches. Brown thrashers, jays, flickers and kingfishers range from eleven and a half to thirteen inches.

It is easy to study the robin in detail, because he has a convenient habit of sitting on a fence-post several minutes at a time, apparently lost in thought. Look at him through the glass till you can see every streak, spot and speck described in the books. Study his coloring till you know the exact shade of his breast. Notice the little white spots in the corners of his tail when he flies, and wait till he shows you his white eyelids. When there is nothing more to discover, you will find that your eyes have been opened. All the rest is a matter of detail. Each bird comes easier than the last; and the veriest tyro who in the beginning could hardly tell an owl from a peacock, ought to accumulate from thirty to forty birds the first season.

If one has a musical gift, it is sometimes easier to identify a bird by its song; but this method never 
seems so certain to me. It is impossible to reproduce a bird's notes in type; the most that can be done is to give a metrical equivalent. Then all birds have a variety of songs. It was years before I heard the blue jay's beautiful bell-like note. The robin's favorite utterance is "Kill him! Cure him! Give him physic!" but he offers many other things beside medical advice. The song-sparrow's cadenza is about as constant as any, but different individuals vary greatly in this respect. The purple finch and the warbling vireo sing very much alike; but the carol of the former is like a long, linkëd chain, while the song of the vireo is much shorter with an abrupt ending: "Brigadier, brigadier, brigate!" Most of the warblers say nothing but zeezee-zee or chee-chee-klur-wee; but when your ear becomes attuned, you can make out the "Trees, trees, murmuring trees!" of the black-throated green. 


\section{BOOKS FOR NATURE-LOVERS.}

Within the past twelve years a multitude of Naturebooks, so called, has been issued from the press. The writer has never seen one that did not contain some help, and she has never seen one that comprehended all that could be said on the subject. The student can hardly consult too large a library; but most of us have to be content with the ownership of a few volumes. The following can be recommended from personal acquaintanceship :

Color Key to North American Birds by Frank M. Chapman. Doubleday, Page \& Co.: \$2.50. If one wishes a general, popular work on the subject, this is undoubtedly the most comprehensive. There are 800 illustrations in black and white with spots of color showing the most striking marks. The descriptions are sufficient and technically accurate; and practically all birds in the country are included.

Guide to the Birds of New England and Eastern New York by Ralph Hoffmann. Houghton \& Mifflin; $\$ 1.50$. For those who wish a smaller book, confined to the species likely to be seen in this region, Hoffmann's work is excellent. The lists of different locali- 
ties are valuable, and there is an entertaining narrative with fine illustrations from drawings. The keys are well arranged for the beginner.

Among the Water-Fowl by Herbert K. Job. Doubleday, Page \& Co.: $\$ 1.35$. This is a labor of love with both pen and camera on the part of the author. There is a distinct literary charm to the work, and the photographs are remarkable. Long and difficult journeys were necessary to secure the material for this book; the water-fowl are less known than any other class.

How to Know the Wild Flowers by Mrs. William Starr Dana. Charles Scribner's Sons: $\$ 2.00$. This was practically the first of the flower-books (the original edition appearing in 1893), and nothing better has ever been written. The present edition contains many fine colored plates beside the excellent drawings. It is a model work, which has brought joy to thousands of readers.

Bog-Trotting for Orchids by Grace Greylock Niles. G. P. Putnam's Sons : $\$ 2.50$. This sumptuous volume describes the treasures in the neighborhood of the Hoosac Valley, the best orchid section in the country. The colored plates are of high artistic excellence, and the other pictures include many striking bits of scen- 
ery as well as groups of orchids in their natural environment. The book is delightfully written, and brings all the pleasure of the author's excursions to the reader.

Mountain Wild Flowers of America by Julia W. Henshaw. Ginn \& Co. : \$2.00. What Mrs. Dana has done for the wild flowers in general, Mrs. Henshaw of Vancouver, B. C., has done for a special and little known class. The book is written in a fascinating style, and there are one hundred full-page photographs of unusual merit, taken by the author.

The Trees and Shrubs of North-Eastern America by Charles S. Newhall. G. P. Putnam's Sons : $\$ 2.00$. This is an excellent popular book, which renders easy the identification of trees and shrubs by their leaves. The work is illustrated by fine outline drawings, and tells just what the average reader wishes to know.

New England Ferns by Helen Eastman of Wells River, Vermont. Houghton \& Mifflin: \$1.25. An admirable little work, written with exceptional clearness and simplicity, and illustrated with some remarkable photographs by the author. The author's place of residence makes the book of special interest to New Hampshire readers.

How to Know the Butterflies by John H. Comstock 
and Anna B. Comstock. D. Appleton \& Co.: \$2.25. From birds and flowers to butterflies is a natural transition. If one goes about with an opera-glass one is obliged in self-defence to begin the study of the butterflies, for they are constantly in the way. This admirable manual of 300 pages by recognized authorities is the best popular work on the subject. It is profusely illustrated by colored plates, which are unusually successful specimens of the printer's art. Like all the best descriptive works dealing with Nature it is pleasant to read as well as to study.

Songs of Nature, edited by John Burroughs. McClure, Phillips \& Co. : $\$ 1.50$. This collection is a valuable anthology of British and American poems relating to the outer world. While we may not find all our favorite authors here, we must acknowledge that the compilation has been made with taste and judgment by one of our foremost Nature-writers, himself a poet of no mean order. It is a book that young students should know by heart. 


\section{LOCAL NAMES IN THIS BOOK.}

The following localities mentioned in this volume are not down in the History of Concord:

Back Ponds, the old bed of the Merrimack, west of Horseshoe Pond.

Batchelder's Mills, on a little-used road running southerly from the Oak Hill Road, East Concord, across the Plains. The place has recently been much changed by pulling down the old mill (February, 1906) and draining the pond.

Bog Road in this book means that running from West Concord, northwest from the cemetery, to Horse Hill. The Dunbarton Bog Road, running past the present Fair Grounds, is now called Clinton Street.

Christian Lane, running past the East Concord station to Christian Shore.

Ferry Lane, the ancient highway bordered by the Herbert estate, running from Main Street opposite the North church to the Merrimack.

Ferrin's Ledge is a sightly elevation in West Concord, east of the road going over Parsonage Hill.

Four-Gate Lane, a private road leading from Christian Shore eastward to the Mountain, East Concord.

Fox Road, sometimes called Fiske Road, leading 
from the Little Pond Road to St. Paul's School. Part of this road goes over high land which gives a fine view of the Uncanoonucs.

Lamprey Place, private grounds near Rollins Park. Long Pond, the familiar name for Penacook Lake. Martin's Cove, the broadest part of Long Pond, opposite the old Henry Martin place, now Sunnyside Farm.

Northern R. R. Track in this volume means that portion of the railway between Pettengill's Crossing and Paradise.

Orchid Brook Road, leading across from the Stickney Hill Road, west of Big Turkey Pond, to the Dunbarton Road near the old Benjamin Hall place.

Pineholm, Miss Eastman's cottage on the Contoocook.

Pottertown, sometimes called Turtletown, is on the north side of Turtle Pond, East Concord.

Rose Bowl, the small, round basin of water on the northerly side of the road near the outlet of Long Pond.

Shattuck Road, leading from the head of Long Pond to the Hopkinton Road.

Walker's Island, the interval north of Horseshoe Pond belonging to the farm of the first minister. 


\title{
BIRDS AND FLOWERS
}

\author{
ABOUT \\ CONCORD, NEW HAMPSHIRE.
}





\title{
BIRDS AND FLOWERS
}

\author{
ABOUT \\ CONCORD, NEW HAMPSHIRE.
}

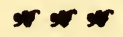

\section{THE FIRST ROBIN.}

It was about half past five on Sunday morning, March 19, that I was aroused by a joyous whoop, which prolonged itself into a series of anapæstic triplets something like this: "Come, wake up! Come, wake up! See, I'm here! See I'm here! Are n't you glad? Are n't you glad?" The bird sang for fifteen or twenty minutes with all the frenzy of a brown thrasher, and it would seem as if his ecstatic carol must have rolled over the whole North End.

Usually I hear the robins some days before I see them; probably, because, though they greet the dawn from the treetops about our houses, they spend their days in the fields or woods in search of food. But this time the fields and woods evidently presented no attractions. When I looked out about nine o'clock, I beheld my musician sitting in the elm. He ap- 
peared big and solid among the bare boughs, but his happy delirium had passed, and his hunched up attitude seemed to say: "If I had had any idea there would be so much snow on the ground, I should not have arrived here last night; but I was deceived by the warm spell of yesterday."

Toward noon he appeared to have recovered his spirits. He was then in the hedge, and every time I spoke to him he turned his big black head and bright yellow bill toward me, apparently responding to my greeting as intelligently as a dog or a horse. We exchanged compliments for several minutes. I asked if I could get him anything to eat, but he shook his wings with a rattling cluck, and flew off to a bare spot in the garden. He evidently wished me to know that he was self-supporting.

Spring begins when the robins get here. I suppose all the children know that in every species the male bird arrives first, preceding the females by about a week. The young bachelors and husbands come to spy out the land. How is it that their wives and sweethearts know when to follow? Perhaps the advance guard tell their mates that if they do not return, all is well and the females can come along without an escort. The reason that the first birds 
are so bright is because they all belong to what Nature evidently intended to be the decorative sex.

On account of the steady cold of the past season, there having been no real thaw during the three winter months, a solid mass of ice and snow has lingered longer than usual; but the birds do not seem especially late. In looking over my records for the past eight years, the earliest date for a robin reads, March. 15, 1902; but a parenthesis is appended, "Heard ten days earlier." This year I shall write, "Seen and heard March 19." Thoreau says he must be a bold man who can declare with certainty that he has seen the first bird or flower of the season in any township. He also says that different years vary a whole month in respect to these dates.

I heard the soft warble of the bluebirds this morning, but I was not fortunate enough to catch a glimpse of their azure backs, though flocks were seen at White Park, and probably in other places. The dingy, snow-clad meadows will be well striped with bare ground in a day or two, and then we shall hear the dear song sparrows with their "Maids, maids, maids, put on the tea-kettle,-ettle,-ettle,-ettle!' But nothing can ever be more welcome than the cheerful shout of the robin. 
I think of Longfellow's lines in "Tales of a Wayside Inn":

"Now was the winter gone and the snow; and Robin the Redbreast

Boasted on bush and tree it was he, it was he and no other That had covered with leaves the Babes in the Wood."

Of even more local interest are the verses of our own New Hampshire poet, Miss Edna Dean Proctor :

"Lark and thrush, I love you well;

But I heard a rarer song

As a wild March evening fell

Bleak New Hampshire's heights along.

Trees were bare and brooks were still;

On Kearsarge the snow was lying;

One red cloud athwart the gray

Faded, faded slow away,

And the north wind down the hill

Like the dirge of hope was sighing.

"Hark! a robin in the elm

Warbling notes so glad and free, Straight he brought a summer realm

Over thousand leagues of sea!"

March 20, 1905. 


\section{A FEATHERED PRINCE.}

I have seen and heard the ruby-crowned kinglet. It was at noon on Thursday, April 13, that a marvelous song arose from our buckthorn hedge. A series of liquid bubbles, then some astonishing trills and arpeggios, and the intricate phrases of an elaborate operatic aria fell upon my delighted ear. I had never seen the bird before, but I knew him at once, for the books all say that the song is past description. Nothing like it comes from any other throat. I know the serene, spiritual hymn of the hermit thrush, the ringing, reverberating joy of the fox sparrow, the ecstatic frenzy of the brown thrasher, the violin-like vocalism of the veery, and the varying melodies of many lesser minstrels, but this differed not in degree, but in kind.

Bubbles rising through water, transformed to music - that is as near as I can express it. The notes welled out of his little throat, almost without consciousness on his part, for apparently all the kinglet's energies were bent on destroying whatever insect life could be found on the twigs of the hedge. The music has been called flute-like, but to me many of the passages 
had a strangely human quality; and I felt as if I were listening to the voice of some famous prima donna.

My glass almost instantly detected the little fellow, greenish olive above, yellowish gray beneath, with two white wing bars. The green and the yellow were quite bright in the sun. I had to follow him to the apple tree back of the barn before he gave me a glimpse of the pretty crimson patch which has so well entitled him to be called the ruby-crowned.

The kinglet is a tiny creature, less than four and one half inches in length. $\mathrm{He}$ is a trifle larger than his kinsman, the golden-crowned, who, next to the humming-bird and the winter wren, is the smallest bird we have. Both kinglets can be seen during the migrations only. The golden-crowned has several times favored me with a visit. $\mathrm{He}$ is really the more beautiful of the two. The coloring of the body is nearly the same in both; but the golden-crowned's head consists of a stripe of orange, encircled by three horse-shoes, first of yellow, second of black, and third of pure, pale gray. Each ring is distinct, and I have never seen anything more exquisite than the combination. The song of the golden-crowned is an unpretentious little ti-ti, ti-ti, ti-ti. Like all Arctic birds, 
he is a fearless little fellow, allowing the observer to approach within a few feet.

The books say that the ruby-crowned kinglet is due about the middle of April; so I think I must have seen one of the first arrivals. He stays here about a month, and then goes north to breed, returning to us for a similar period late in September. Somewhere I have seen that the song of the ruby-crowned is one of the most remarkable sounds in nature, for the whole vocal apparatus is scarcely larger than a pea, while his gurgling music can be heard at a distance of several hundred feet.

Let us give this little feathered prince a royal welcome.

$$
\text { April 14, } 1905 .
$$




\section{BIRDS AFTER THE SNOW STORM.}

Last Saturday, April 16, it really seemed as if "old Hiems' icy crown" had returned to mock the bursting buds of spring. I saw the bluebirds wading about disconsolately in several inches of snow, and the robins were clinging to the buckthorn hedge eating the black berries, which I had supposed were poisonous; but the berries appear to have served in good stead as hunger rations this cold spring.

- Monday forenoon the sun was tolerably warm; most of the snow had disappeared from the garden; so I walked forth therein to see what I could see. A female downy woodpecker was pecking at the suet, a gorgeous male bluebird was perched on the fence rail; then I saw to my great delight a fox sparrow on the apple tree back of the barn. His bright rust-red rump, wings and tail are enough to warm the landscape on these chilly days. He was the first of his kind I had seen this spring, though they are very early migrants, and were reported here two weeks ago.

I heard the soft tseep of a junco in the cherry tree and turned to look at his pink nose, which is so con- 
spicuous in his dark face. Then I caught a glimpse of a group of robins and song sparrows on the ground. There seemed to be one alien member flitting about, a bird of peculiarly soft coloring and graceful figure. I drew nearer, and there he was, the bird of birds, the archangel of the summer choir, the hermit thrush. He was not in the least shy. I saw him twenty times yesterday morning, and again in the afternoon, nearly always on the ground, often not more than ten feet away. He posed for me in the most obliging fashion, so that I could see him from every point of view. Once he was kind enough to stand directly under the branch whereon the fox sparrow was sitting, so that I could compare the birds at my leisure.

To a novice, who catches a hasty glimpse only, the fox sparrow and the hermit thrush might look very much alike. They are practically of the same length, a trifle over seven inches; each has a bright squirrelred tail and a spotted breast; but when placed near together, the differences are marked. The bills alone should distinguish them, for there is no similarity between the conical one of the sparrow and the long, slender one of the thrush. Their figures are quite unlike, the sparrow being rather heavy and "chunky," 
while the thrush is peculiarly delicate and graceful in outline with a very erect carriage. Their coloring differs considerably when closely compared. The sparrow has a large blotch of ash-grey on his crown, and more or less of the same color streaked through his back. His breast is heavily and thickly spotted with reddish brown. The thrush's head and back are an exquisite shade of olive brown, which blends beautifully into the red of his tail, while his breast is marked with the delicate brown arrow-heads characteristic of his species. Thrushes are usually considered inconspicuous and unobtrusive in dress, but in the sunlight the olive brown shows a peculiarly soft and harmonious tint, making the coloring of the fox sparrow look crude and blotchy by contrast. There are other minor differences, such as the yellow eyering of the thrush, but I have indicated the chief points. Both are famous singers, the best of their kind.

I had never seen the thrush on the ground before; in fact, a look at him under any circumstances is a rare sight. When he moved, he made a funny little run, much like the robins. He did not scratch like the sparrows, but he occasionally picked things out from the dead leaves. Once he ran up to a decayed apple 
tree and extracted something, probably grubs, from the powdered interior. Now and then he raised and lowered his tail, a characteristic movement, but I did not hear him utter a sound. Neither the sparrow nor the thrush has found his voice yet. Their manner was quite unlike. The sparrow appeared shy and awkward, and did not welcome a near approach, while the thrush seemed the embodiment of gentleness and high breeding.

The hermit is the first of the thrushes to come north, being due here about the middle of April. All the birds have been delayed by the unusually cold season; hence I feel that our premises have been honored by a visit of a pioneer of this noble tribe.

April 16, 1904. 


\section{A WARBLER SHOWER.}

The rain was well over by one o'clock on Thursday, May fourth, and I started out to try the possibilities of our back yard. The garden was alive with birds. Yellow-rumped or myrtle warblers, which I had seen in numbers on the meadows about Ferry Lane the day before, were flitting everywhere. The spot on their backs shone like a gold dollar, so that the air seemed to be filled with flying coin. This bird is usually considered the first warbler to arrive, and as he possesses three yellow patches beside his rump-one on each side the breast and a stripe through the crown, his uniform of slate-blue, black and white is enlivened with a considerable amount of gold lace. Two or three black and white warblers, which I call the zebra bird, on account of his stripes, were scrambling up and down the tree trunks.

What is that graceful shape scurrying through the wild cherry jungle near the fence? Ah, there is no mistaking that aristocratic mien and that soft shade of olive brown with the squirrel-red tail. It is the hermit thrush, the archangel of the feathered choir. How true it is that all things come to him who waits. 
Years ago I thought this bird invisible to human eyes. It seemed that his ethereal music could never have proceeded from a mortal body. Now he comes every spring and fall into our back yard. He reserves his hymn for the woods, but he gladdens our eyes with his presence.

A brown creeper, which I had not seen for two months, was sliding up a pear tree, flat against the bark. Then, to my great delight, I saw on the fence a white-crowned sparrow. The white-throated sparrows arrived a week ago, and the garden has been full of their "Peabody, Peabody" notes ever since, but the white-crowned is a rarity. I had seen but one before, on May 21, 1903, in our back yard. Until I saw that one, I had always feared that the two cousins might look so much alike that it would need a magnifying glass to distinguish them; but there is no difficulty. The white-crowned has a broad band of pure white reaching from his bill to his nape, while a narrower band encircles his head. John Burroughs, considers him the handsomest of the sparrows. $\mathrm{He}$ is indeed a beauty, though his extremely broad "part" gives him a somewhat bald-headed effect. A little later, I saw another bird with a striking central stripe. This time it was orange-brown, set between two bands of 
black, the distinctive feature of the ovenbird. He was walking about among the hermit thrushes, and his olive back and spotted breast always make me think him of their kin; but the books classify him as a warbler; why, I never could understand.

But the best part of the afternoon was to be afforded by the larch in the side yard. It seemed as if a warbler were swinging from every one of its feathery twigs. There were dozens of yellow-rumps, then a yellow warbler proper. I soon recognized the blue-headed Nashville and the bay-crowned palm warblers, both bright yellow underneath. Then came the crown of delight, for there swung into view the rarest and most beautiful of all, the far-famed Blackburnian. But twice before had I seen this gem, in 1900 and 1904. I suppose we should "blunt the fine point of seldom pleasure" if he came too often; but one look at that throat and head plated with scales of burnished gold is enough for a whole May merry-making. The female ruby-crowned kinglet spent the entire afternoon in the larch and in the hedge. She allowed me to approach within two feet of her, but not a note could I get from her gifted throat except a snappish cluck when I tried to take her in my hand. Of course song and chipping sparrows were ubiquitous, with oc- 
casional bluebirds and robins, but I noticed only one chebec, who arrived May first, while the chewink, who came yesterday, evidently said hail and farewell on the same day. The purple finches, who have brightened our garden for the last two weeks, were unexplainedly absent. Later in the afternoon I saw the veery in a neighbor's yard.

May 6, 1905. 


\section{THE SPRING RUSH.}

"When the wind comes up from Cuba

And the birds are on the wing, And my heart is patting juba

To the banjo of the spring."

Hovey.

Not once has the wind come up from Cuba this season, but the birds are here. Their punctuality always surprises me. The very first arrivals vary according to the temperature. Thus Thoreau records the date of the earliest bluebirds all the way from February 24 to March 24 in his Concord. The first spring flowers show the same variation in our land of the lingering snow. But when May comes and presumably settled weather, the same birds appear at practically the same dates, year after year. Old Farmer Leavitt, without whose almanac we could not keep house, would be perfectly safe in writing opposite May 10: "Look out for gold robins and catbirds about this time." I am assuming that all my readers know that the gold robin and the Baltimore oriole are identical, though a few years ago I was walking on a college campus with some members of the faculty, and they did not know. 
What a joy and comfort the orioles and the catbirds are, though among the most common frequenters of our elms and hedges. When I hear the cheerful pipe of the oriole and see that flash of flame dart into the weeping-ash tree at the corner of our piazza, I know that apple-blossoms and all sorts of good things are at hand. As for the catbird, I class him with the bobolink, and I hardly know which of the rollicking clowns I prefer. The eatbird is so knowing and so "sassy." I have heard one sing for twenty minutes at a time, perched on the very top of one of our cherry trees. He poured forth a medley like a garden of thrushes, interrupting himself now and then to squeal out a "mew" at me, which I suppose is his growl of displeasure. They imitate everything from a cock to a canary, and I heard one this morning repeating "whippoorwill." Perhaps I ought to add that I also saw him, for the imitation was perfect enough to deceive.

Speaking of the dates of arrival makes me wish to advise every bird or flower lover to write down when and where the treasure is first seen. I put these memoranda against the description in my favorite books, and then they are always at hand when wanted. I never take a journey anywhere, even if it is no 
farther than to Garvin Hill or the Contoocook River that I do not endeavor to see something new. Records of this sort take up very little room and they are the best possible reminders of pleasant outings. I long ago gave up collecting "souvenirs" except the choicest photographs, and even these, unless expensively preserved, clutter up the house after a time: but the memory of a bird or a flower brings the whole picture before your eye. Thus I open Mrs. Dana's "How to Know the Wild Flowers," my vade mecum, and see the name Hydrophyllum Virginicum or waterleaf, and read the date, "July 6, 1898, Rainbow Falls, near Lower Au Sable Lake, the Adirondacks." My mind instantly reverts to that shimmering play of color over a precipice where "the water spills itself in smoke," and I recall the picturesque gorge in one of the most beautiful regions I have ever visited. All the mountain summits I have ever climbed are linked together by the little Potentilla tridentata or white three-toothed cinquefoil, which I always find growing upon those exposed heights.

Perhaps I ought to modify my statement about the birds' appearing at a certain date. Although the majority of them follow the prescribed time-tables, yet there are always individual tourists, and one may 
stumble upon anything anywhere any time. Thus the crossbills are supposed to be winter visitors only, but they appeared to me in mid-summer at Wakefield. For years I have been hunting for the fox sparrow, who is supposed to be one of our earliest migrants. I thought he had gone north a month ago; but last' Tuesday morning, May 13, I was aroused by what Miss Merriam calls the "loud, ringing, liquid notes." I went out doors, expecting to find a prima donna, either of the purple finch or grosbeak species. After I had followed the inspiring song from tree to tree, I was rewarded by seeing the bird stop to drink at the pond in our garden. Then I discovered that, notwithstanding his large size, he is the most sparrowy of the sparrows, and that I had found my long-sought bird, where I find everything,-in my back yard.

Perhaps I may end, as I began, this little article by a quotation from Richard Hovey, who seems to me the very poet of the spring. It is from his poem which begins,

"Make me over, mother April,
When the sap begins to stir!"

This is the stanza which I like: 
"Set me in the urge and tide-drift

of the streaming hosts a-wing!

Breasts of scarlet, throats of yellow,

Raucous challenge, wooings mellow-

Every migrant is my fellow,

Making northward with the spring.

Loose me in the urge and tide-drift

Of the streaming hosts a-wing!"

May 16, 1902. 


\section{THE HERMIT OF THE WOOD.}

From childhood I have been familiar with the "divine soprano" of the hermit thrush, the song which John Burroughs calls the finest sound in Nature. I think we never drove through the Dark Plains on a quiet summer afternoon that we did not hear this chime of silver bells amid the tops of the murmuring pines. But I was always told that it was hopeless to look for the bird. My father and my uncle, both woodsmen, said that they had searched for hours to find the source of this heavenly music, but that the bird was the shyest of all feathered creatures and was never seen. I grew up with the idea that, like Wordsworth's Cuckoo, he was not bird at all, but a wandering voice. There seemed something appropriate in this mystery and seclusion, for there is a peculiarly spiritual quality about the music; and when several hermits were singing in the pines, as they always were on Sunday afternoons, it seemed like an angelic choir in the dim aisles of a cathedral.

Of late years since I have learned the possibilities of an opera-glass, and that even an amateur who keeps his eyes open may expect to find anything anywhere, 
I have sometimes dared to hope that I might catch a distant glimpse of the magic minstrel. One such view I had at Au Sable Chasm in July, 1898, when a hermit perched on a blasted pine on the opposite side of the gorge and poured forth his soul at eventide; but he was too far away for recognition. We saw nothing but a dusky silhouette in the evening light. Still, that was a satisfaction, for I knew then that the bird is a live creature, who makes his home on earth.

On Tuesday, May 14, 1901, my great piece of good luck befell. We had been rambling about the Turkey Brook region in Millville, and had seen nothing more remarkable than a catbird, a redstart, a yellow warbler, a bobolink and a female bluebird on a mullein stalk. We had resumed our drive on the Silk Farm Road, intending to see what the meadows in the Iron Works district might afford.

As we approached the top of Silver Hill my attention was at once arrested by the ethereal melody, which has grown rare, alas! since the pines about Concord have been ruthlessly slaughtered. We drove nearer, and there on a small birch just inside the stone wall, not a rod from our wagon, sat the poet of America, his little bill quivering with ecstasy and a fountain of music gushing from his magic throat. We 
could see him as plainly as the chipbird we had heard trilling an hour ago.

Like most gifted souls, he is very plain in his attire. But four fifths of an inch longer than the song sparrow, with a dusky brown back reddening towards the tail, he showed a marked yellow ring around the eye as his most striking characteristic. His speckled breast was partly turned from us. He let us survey him a minute or two, then flew to the edge of the wood where he continued to fill the air with his silvery chimes for more than a quarter of an hour.

I never hear this song without regretting that it has not been fitly celebrated in verse. Lowell has immortalized the bobolink and J. T. Trowbridge, the wood pewee. Emerson has written of the song sparrow and the chickadee. Celia Thaxter has sung of the sandpiper and the wild sea fowl; and nearly all our poets have incidental references to the oriole, the red-winged blackbird, the veery, the goldfinch and other typical American birds. Browning has a famous couplet about the thrush, but not the hermit, for his notes are too spiritual to be called a "fine, careless rapture."

If the lamented Richard Hovey had lived, perhaps 
he could have produced a truly American lyric about our peerless songster. Hovey was a poet from whom great things were expected. His "Men of Dartmouth" is the finest college song ever written. Meanwhile, I suppose our thrush must wait for a genius like Shelley before literature will enshrine him in the niche to which Nature has already assigned him.

Thus far we have nothing better in its way than Trowbridge's Wood Pewee. Here are a few lines from this little known poem:

"Only a little forest brook

The farthest hem of silence shook;

When in the hollow shades I heard,-

Was it a spirit or a bird?

Or, strayed from Eden, desolate,

Some Peri calling to her mate,

Whom nevermore her mate would cheer?

'Pe-ri! pe-ri! peer!'

"Long-drawn and clear its closes were, As if the hand of Music through The sombre robe of Silence drew

A thread of golden gossamer, So pure a flute the fairy blew. 
"With greenish gold its vest was fringed, Its tiny cap was ebon-tinged, With ivory pale its wings were barred, And its dark eyes were tender-starred. 'Dear bird,' I said, 'what is thy name?' And thrice the mournful answer came, So faint and far, and yet so near,'Pewee! pewee! peer!',

May 25, 1901. 


\section{THE MERRY MONTH OF MAY. \\ "And smalé foulés maken melodie \\ That slepen al the night with open eye."}

Chaucer.

Every bright morning at this season I feel like quoting the line from Cymbeline, "This is a good day not to keep house!" I grudge every minute that I must spend indoors. What a pity that our manner of living decrees that spring cleaning and spring sewing should come at this time! We do these disagreeable duties now, thereby losing all "the boyhood of the year, " in order that later, when the country is hot and dusty, we may disport ourselves on the piazza of a summer hotel and sit down after breakfast and play whist. Happy is the woman who knows how to seize the day ere it flies, and who times her leisure by the coming of the birds.

This spring has not been a notable one in bird annals. I had hoped that the cold weather, which was supposed to account for the host of warblers in 1900, might have a similar effect this year, but it has not, so far as I can learn. Still there is always enough to see. Why is it that some birds are comparatively 
abundant in a certain locality one year, and almost unknown the next? Is it weather, food supply or cats? For instance, the goldfinch, a very common and charming little songster, appeared in our garden but once last year to my knowledge, while this year there have been whole choruses of them in our apple trees, and their bright little black-trimmed yellow bodies have been almost as common as gold robins. On the other hand, the veery, the chewink and the whitethroated sparrow, which were running about under our hedge last year, have not visited us this season and I have had to seek them at the Reservoir and the Pumping Station.

I had the pleasure of making a new warbler acquaintance this spring, and, as usual, in our back yard. When I first caught sight of his black and yellow in the choke-cherry thicket, I thought it must be one of the goldfinches or else a Maryland yellowthroat, who has been shouting his "rig-a-jig, rig-a-jig", in our bushes the past month. But a near view showed him to be unusually small, even for a warbler, being only five inches long, and unusually unmarked for that variegated tribe, being simply olive green above, plain yellow below, with a little black cap, as round as a button, on top of his head. I soon identi- 
fied him as the Wilson's warbler, and I found an ex. cellent picture of him in Miss Merriam's "Birds of Village and Field."

Other people beside myself have commented on the scarcity of purple finches. The only one this year that I have seen near our house, perched on our front gate-post on May 20. He appeared to be in an advanced state of frenzy or intoxication, for every rosy feather on his head stood erect and he was dancing with both wings, both legs and his tail. I could not understand such excitement, for the purple finch has always appeared to me a very meek and gentle bird. I was delighted, however, on consulting Miss Merriam's book, to find that these antics are very common in the spring and to see a perfect picture by Seton-Thompson, representing the bird in this very attitude.

That day, May 20, I marked with red in my calendar, for, beside the rosy finch (it is a perversion to call him purple), I saw later, at the Reservoir, the scarlet tanager, the rose-breasted grosbeak (both for the first time this year), beside the redstart and other lesser brilliants. I also saw a woodchuck. The tanager is the most fiery thing that flies. I am glad to note that he is becoming rather abundant these last 
two years; still, to see him is always accounted glory enough for one day. I saw him twice on his favorite tree that afternoon, and I remembered Mr. L. J. Rundlett's advice, given some years ago: "Always look for the tanager in a young oak grove."

The Reservoir appears to be a good place for birds, for next week, in company with the Wild Flower Club, I saw a bird new to me, the great crested flycatcher. He is great only by comparison with his least relative, the chebec. We were not positive about his identity till we saw a perfect colored picture of him by Seton-Thompson in Chapman's "Bird Life." The same wonderfully accurate artist has a page in Miss Merriam's book called "The King and his Kin," in which he contrasts the great and least flycatchers, the phoebe, pewee and kingbird.

May 31, 1902. 


\section{TWO RARE WARBLERS.}

Of all our native birds, the warblers are the most difficult to identify. They are so tiny, being little more than five inches in length, and so incessantly active, that, despite their exquisite coloring, the casual observer never sees them. But once become acquainted with one of the fascinating fire-flies (that seems an appropriate name for anything so brilliant and elusive), and you will never rest until you know the twenty-nine or more varieties we may expect to see about Concord. Do not hope to be entranced by their melody, for they are called warblers apparently because they do not sing. Here are two rare ones, which I saw for the first time in 1905.

Just after supper on May 17, one of those cold, gray nights, which made the third week of this month so depressing, I noticed from the window a new bird in the hedge. I was sure that he was a warbler. Just how I knew that he was new I cannot say, except by his entire lack of bars and blotches. The warblers as a rule are a ring-streaked and speckled tribe, and this bird was more Quakerish than a vireo or a flycatcher. He was very tame, or rather he was feeding so indus- 
triously that I watched him at yard-length for several minutes. Pure white underneath, olive above with a grayish head; not a spot on him anywhere, and not a tinge of yellow. I sought the books, and by good luck I stumbled upon him instantly in Hoffmann's "Birds of New England." I felt quite elated when I read that on account of his entire absence of markings the Tennessee is less likely to be seen in this region than any other warbler, and may be found only by the most expert field ornithologists.

The bay-breasted warbler I saw to less advantage, but many of my co-gazers have beheld him several times in White Park. Just a week after the Tennessee appeared, we saw the bay-breasted in the Wallace yard on Pearl street. He was high up in the elm, and four of us climbed out on the roof of the piazza at imminent risk. The sunset light threw a deep reddish cast over his chestnut markings, and we thought him very beautiful. We were not sure what he was till we found him pictured in Schuyler Mathew's latest book. Colored pictures of birds are frequently the most misleading kind of chromos, but this one looked just as we saw him.

The magnolia, which some people consider the most beautiful of the warblers, not even excepting the 
Blackburnian, lived in the spruces on the west side of the Pumping Station all through the middle of May. His orange-throated compeer, the Blackburnian, was frequently seen there too, also the Canadian. The latter's necklace seems a little scrimped after one has seen the magnificent trailing pendants of the magnolia. The black-poll and the Wilson's (the latter might be called the black-crowned) were numerous in our garden thickets last week, while all these and other warblers could be found on the western side of White Park.

May 31, 1905. 


\section{JEWELS IN THE STREET.}

The month of May, 1900, will be remembered for its cold temperature and its wealth of bird life. All through New England articles have appeared in the local papers, commenting on the treasures at our doors. Feathered gems, for which the enthusiast commonly searches the dark, unfathomed caves of the remote woods, have hopped along the sidewalks almost under our feet; birds which the books declare rare have haunted our back yards.

Doubtless the weather has been largely responsible for this pleasant invasion. The cold checked the migrations and called a halt in the progress of the winged army; but I like to think that the popular interest in Nature, the work of the Audubon society, and the opera-glass in the hands of thousands of admiring amateurs-in other words, the cordial welcome that has been shown the host, may have had something to do with its stay among us.

On Monday, May 7, the Wild Flower Club identified the olive and yellow pine warbler in the evergreens above Paradise. We had previously seen him at Camp Weetamoo on May day, but were not quite sure of his name. On coming home by the Back 
Ponds, near Horseshoe, where the red-winged blackbird sounds his quonk-a-ree, we saw a large flock of the pretty yellow-rumped warblers, which I found very abundant on the summit of Moosilauke last summer. Some tree swallows, which were perched on the telegraph wire, obligingly sat unmoved for several minutes while we admired their silver vests and tried to determine whether their iridescent coats were metallic green, blue or purple black.

Wednesday afternoon, May 9, at Gen. J. N. Patterson's, I saw nine different species of birds in the course of an hour, five of which were warblers. The trees were fairly swarming with them. The parula or blue yellow-backed were the most noticeable. A company of them were industriously exploring every bud and twig of an apple tree, and so busy and happy were they that they did not mind my immediate presence. Another tree was filled with olive backs, yellow breasts and bluish gray heads, which I judged meant a flock of Nashville warblers. The handsome blackthroated green warbler delighted me with his bright yellow head and inverted black $\mathrm{V}$ on his breast, and presently my eyes were dazzled by a glimpse of the far-famed Blackburnian. I had never seen him before, but there was no mistaking those blazing orange 
cheeks and throat. The variegated chestnut-sided, with his pretty greenish yellow crown, a warbler I find common everywhere in summer, was also present.

On Thursday, May 10, while driving on the Little Pond Road, I again saw my friend, the black-throated green, and while getting out to look at a flock of whitethroated sparrows which were scratching like hens among the dried oak leaves, and calling, "Peabody, Peabody," the black-throated blue warbler flew into view. I think he is quite as handsome as his congener of the inverted $\mathrm{V}$, and much rarer. If you are fortunate enough to see him, he may easily be distinguished by the square white spot on the wing, his characteristic and unique mark.

On May 13, by the Back Ponds near the Northern track, I saw the great bald eagle. At first we could not believe our good luck, for though the bird may be found anywhere in North America, the books declare that the sight of him is always an event. He was perched on an upper limb of a tall tree, and when he flew there was no mistaking those great dusky pinions and that snowy head and tail, which give the appearance of a white body. We got near enough to him to hear his "turkey"' notes. By the law of contrast, at almost the same time and place I saw the pretty 
little black-poll warbler, who was new to me, though I had almost laid my hand many times this spring on his near relative, the black and white creeper, who is similarly attired in half mourning.

On May 14 the Wild Flower Club in climbing Rattlesnake Hill, saw the black-throated green and the black-throated blue warblers, the rare magnolia warbler with his ashen crown and bright yellow breast striped with black and the beautiful solitary vireo. In the pasture on the summit we found the red-billed field sparrow and a little striped what-is-it skurrying through the grass, which nobody has been able to identify. (I think now, 1903, that it was the northern water-thrush that we saw.) I first noticed the saucy catbirds that day, though they are usually due in our hedge about the tenth of May. The chickadees and woodpeckers were omnipresent, as usual, and we stirred up some partridges, as we nearly always do on our tramps.

On May 17 in a swamp on the north side of Franklin street I again saw the solitary vireo, also the wood thrush, beside the yellow warbler and a dozen other kinds which had grown quite familiar. The oven bird was shouting "teacher, teacher," at the top of his voice, but I did not see him. The wood thrush is 
considered rare north of Massachusetts, but I have occasionally found him about Concord. $\mathrm{He}$ is easily distinguished by his large size and the pronounced reddish tint of the head and shoulders. The hermit and the olive-backed thrush are seen here by good observers. The best known member of this fascinating family is the veery, whose smooth, uniformly tawny coat I have seen many times this spring, both in town and out.

It has not been necessary to go far a-field to see the birds this May. The redstart, which looks like a burnt orange or gold robin on a small scale, has flown into open doors at the North End. His mate, who wears olive brown and sulphur yellow in place of her lord's black and flame color, puzzled me very much a few years ago till I discovered that the blotched markings and spread fantails of the two sexes are identical. The scarlet tanager has been a familiar visitor in many yards, while the black-masked Maryland yellow-throat, who cries "What a pity!" and some of the other warblers, have fairly haunted our shrubbery.

In our own back yard on May 21 I saw the magnolia warbler investigating every spray of a large woodbine which covers the shed. On May 22 and for two succeeding days the beautiful Canadian warbler 
with his blue-gray head and jet necklace hanging about his bright yellow throat was much in evidence, and on May $23 \mathrm{I}$ saw the parula warbler preening his feathers in our hedge and suffering me to come so near that I could behold his minutest markings. I have seen all the vireos this spring with the exception of the white-eyed. The yellow-throated flew into our hedge May 27. The red-eyed is one of the latest birds to arrive, but you know when he gets here. For the last two weeks he has been reiterating, "I see it! I know it! Do you hear me? Do you believe it?" with a persistency which has won for him the title of the preacher bird.

For those who are never interested in a subject unless some practical good comes out of it, I will say that there ought not to be a bug, worm or caterpillar left in Concord this summer. Our apple crop and every other crop should be enormous, for every one of the beautiful little winged jewels that I have seen has been working incessantly, as if he had on his mind the contract for destroying the whole insect life of North America. What a comfort it would be if we could hire human helpers who would display a tithe of their industry and ambition.

June 5, 1900. 


\section{DOWN FERRY LANE.}

"There were Bobolincon, Wadolincon, Winterseeble, Conqueedle-

A livelier set was never led by tabor, pipe, or fiddle,Crying, 'Phew, shew, Wadolincon, see, see Bobolincon, Down among the tickletops, hiding in the buttercups!'

I know the saucy chap, I see his shining cap

Bobbing in the clover there-see, see, see!"

Wilson Flagg.

Come with me to the meadows in June and hear the bobolinks sing! Let us start at the head of Ferry Lane, opposite the North Church, drop down the hill and over the track, and follow this ancient thoroughfare even to the river bank. All around us lie the fertile intervals that caused the settlement of Concord. Hereabout are the bends in the river that gave us the Indian name of Penacook, Crooked Place. Just across lies Sugar Ball, the kettle-shaped hollow scooped out of the Bluffs, one of the most historic spots in town. On its northerly side tradition locates the famous Indian fort; on the plain toward the east stands the monument commemorating the first religious service held in Central New Hampshire; on its southern rim, through the fringe of birches, out- 
spreads the striking picture of Kearsarge looming over the Merrimack valley.

But let us not hasten to our journey's end; this is a road where we can afford to linger. When we have passed the last dwelling and the last frescoed roof of the "sarsaparilla" barns, we come to the meadows with their drifts of bluets, like foam on the waves; and the orchestra tunes up.

"June's bridesman, poet of the year,

Gladness on wings, the bobolink, is here;

Half-hid, in tip-top apple-blooms he swings,

Or climbs against the breeze with quivering wings.

Or, giving way to't in mock despair,

Runs down, a brook of laughter, through the air."

But not even Lowell with his "brook of laughter", has caught the spirit of the bobolink as has Wilson Flagg in the jig whose snatch is quoted at the beginning of this article. The "bobbies" are rising and falling all around us on the meadows, clinging to the grass stems, perching on the fence rails, fluttering over the ridgepole of the barns. They are dressed as for a "Looking Backward" dance; for the bobolink is the only bird that wears his shirt front and his yellow necktie foreside hindmost. 
"Every one's a funny fellow; every one's a little mellow; Follow, follow, follow, follow, o'er the hill and in the hollow!

Merrily, merrily, there they hie; now they rise and now they fly;

Happy's the wooing that's speedily doing, that's speedily doing,

That's merry and over with the bloom of the clover! Bobolincon, Wadolincon, Winterseeble, follow, follow me!"

These are the butterfly days of the bobolink, for he undergoes almost as much a metamorphosis as does the caterpillar in the chrysalis. Our jaunty friend arrives on our meadows about the second week in May, but he is entirely dumb by the Fourth of July. His little family are usually on their feet when haying begins, his striking wedding garments are exchanged for a dull, mixed brown traveling suit, made out of the same piece as his wife's, and by the middle of August he is on his way South, a changed being, there to become the reed bird of Virginia and the rice bird of the Carolinas. Let us be thankful that he spends his honeymoon with us, and so long as we have his music, other people can keep the game.

Long before the bobolink comes and months after he is gone, we have the meadowlark. Do you hear 
their plaintive whistle, piercing sweet, "Spring is here! Spring is here!"? They abound on our meadows, but you may spend a whole afternoon there without getting a good look at one. Then suddenly several brown backs with white outer tail-feathers may rise in front of you with heavy, awkward flight, propel themselves a little way, and settle down again. The meadowlark has learned by sad experience not to expose his bright yellow breast with its black crescent to the casual stranger. Now and then I have seen them stretching their lean heads up through the grass, apparently standing on tiptoe, with their waistcoats gleaming golden as a dandelion.

Let us wander out to Fort Eddy and sit in the shade of the ice-house. The pond in front of us is one of the many old beds of the river, the track which the wayward Merrimack leaves of its wanderings. We are told that a few years ago a snowy owl drifted down from the Arctic regions and made his home in this ice-house all summer, going in and out by an opening under the peak of the roof. His tribe are occasionally seen here in winter. The only pair of house wrens I have ever found in Concord were rearing their brood in one of the joists supporting the ice slide. There was such a nestful that I hoped we 
should soon have wrens to spare in Concord, but I have never seen one of the perk little chatterers since.

A jet black bird with orange-red epaulettes flies past, and I see that we are in the home of the redwings, though their favorite haunt is in the alder thickets of the Back Ponds, where they breed in great numbers. I hear a lively whoop from the bushes, and then follows an exultant college yell, which one of my musical friends has rendered: "Look-a-here! Look-ahere! See me! See me! Happy! Happy! He-he-heKickapoo! Kickapoo! Kyrie! Kyrie! Here!' Looking up, I see the brown thrasher dive into the bushes. $\mathrm{He}$ is a tawny bird with brass eyes and a long tail, and he plunges into the thicket like a swimmer. No one else sings with such frenzied abandon. Go up to the young growth south of Blossom Hill, if you wish to hear his ecstatic love-making.

But we must not linger here, if we are to get to the river. The road soon becomes little more than a carttrack, but the bushes are full of warblers. The summer yellow-birds make this region their special home, and they look like lumps of gold dodging through the branches; the illusion is not lost if you catch a glimpse of the rusty red streaks on their breasts. The grass is so rich in the meadows that the Lane is not a spe- 
cially good place for flowers, but if it were July we should see the pretty purple-blue racemes of the vetch running riot in the fence corners. Here, too, is the place where the yellow threads of the dodder, encrusted with close, white flower clusters, writhe about the stems of the goldenrod and asters which they are choking in their parasitic grasp.

Pleasant it is at last to sit on the edge of the steep bank and watch the water eddying at our feet. The swift current runs like the sands of Time. On the opposite shore is a broad, sandy beach, where the spotted sandpiper teeters. Just beyond the beach is a fine grove of maple and elm where the cows love to wander. There is a thin growth of grass in this grove, but no underbrush; perhaps because the land is so often overflowed. The afternoon that I visited it, June fourth, the tree-trunks were drenched in a gold-green light, which sifted through the dense, tender foliage. The place looked like an English park. Back of the grove is another old bed of the river, and then come the three fine farms of Sugar Ball. We can see none of the buildings from here, except the sap-house in the grove, belonging to the Lougees.

On our side of the river a flirting flicker is preening his feathers on a branch, apparently turning him- 
self inside out to display his variegated plumage. An answering "wicky, wicky" comes from across the river. I used to think the flicker the handsomest bird that flew when my brothers shot game on the meadows. We called him "harriwicket" in those days. The flickers nest in some of the hollow stumps farther up the Lane; but the only occupied house of theirs I ever found was near the pond at Blossom Hill. I was casually passing by a big tree one day when I heard a soft bur-r-r-r. I looked about, but there was no telegraph pole in sight, so it could not be the humming of the wires. There was no squirrel or other animal overhead. It quite startled me when I found that the murmur was coming from the inside of an apparently sound tree. Could a Dryad be imprisoned there? I had to hunt to find the hole which was as high as my head, and almost concealed by a fold in the bark. I thrust my arm down far as it would go, and the hungry younglings stretched their necks and bit my fingers. I might not have been sure they were infant flickers, had I not heard an anxious note near by, and looked to see the mother bird clinging to a neighboring tree-trunk, and making a gorgeous splash of color with her white rump and gold-lined wings and tail. The scarlet nape is absent in the 
female, but the beautiful, round-spotted, lilac-brown breast is the same in both sexes, making this bird the handsomest of the handsome tribe of woodpeckers.

As we sit here on the river bank I like to think of the old days before the bridges, when the name Ferry Lane was literally true, and a boat plied between opposite shores. The ferry was maintained till 1831 by Benjamin Kimball of Sugar Ball; but the building of the Free Bridge (1839) rendered it useless. There were two other ferries in town, where the East Concord and the Lower Bridge now stand, and during the eighteenth century there was no other means of crossing the river. Primitive traffic it must have been in those days, much of it on foot or horseback. The charge was sixpence apiece for each man or horse, and fourpence for each "horned beast." The carts were home-made, and there was scarcely a chaise or curricle in town till after the Revolution.

If you do not mind the walk, we will go home by way of the Fan. We keep northward past the Fort Eddy Pond and ice-house and presently come to the edge of a great interval made by an enormous bow in the river. Here we see the oldest cultivated land in town. For a hundred and eighty years these meadows have been mown. On the upland lies the Brad- 
ley hay-field, and in the interval below, land that used to belong to Capt. Samuel Coffin and other North End worthies. Not far away spreads the Walker farm, encircled by Horseshoe Pond and cut through by Wattanummon's Brook. Here is where the farmers "thank the spring flood for its fertile slime." On these meadows my ancestors shot wild turkeys, our finest American bird, well into the nineteenth century. Here is where my brothers used to go gunning in their youth and bring home sand-peeps, plover, ring-necks and yellow-legs. Most of the game birds, of which so large a list has been furnished for this book, can be seen in this region and kindred places along the Merrimack.

I know the bushes on the river bank as the haunt of the black-billed cuckoo. A few years ago I saw an otter swimming near shore. Mink used to be trapped here in great numbers. The only glimpse I ever had of one was October 30, 1903, at the Asylum causeway leading to the little island in Long Pond. The white spot on his throat was the size and shape of a silver dollar. He regarded our boat with much interest and little fear. There is one flower that grows on the Fan Road, which I have not noticed elsewhere; it is the Smilacina stellata or star-flowered Solomon's seal. 
But we are lingering late. The nighthawks are squawking overhead, the swifts are circling about, and the swallows fly low. The air is pure and sweet, but the mists are rising. There is a purple gloom on Rattlesnake, and the State House dome and the spires of Concord look faint in the evening light. We will go home by the pass-way under the Montreal track while an Emily Dickinson sunset still lingers over Horseshoe Pond:

"There seemed a purple stile

Which little yellow boys and girls

Were climbing all the while.

Till when they reached the other side, A dominie in gray

Put gently up the evening bars, And led the flock away."

June 9, 1906. 


\section{OUR WINTER VISITORS.}

Few people know how many birds we have during the cold weather till they read the books and keep their eyes open. Winter is an excellent time in which to begin the study of birds. Being few in number, they are not confusing as in May, and they are easily seen among the bare trees. During the winter of 1904-05 four species were daily visitors to the arbor vitæ tree in front of our bay window. They were the white-breasted nuthatch, the downy woodpecker, the chickadee and the brown creeper. All that is needed to attract them is a piece of suet nailed to a tree.

In November, or as soon as the days as well as the nights are cold, I put out the suet. In 1901 I melted some mutton fat and poured it over the trunk of the tree. The climbers seem especially to like this arrangement, and every day I would see them chiselling out the bits of fat with their slender bills.

The nuthatch is the bird most easily attracted to the house. He is very fond of the great elms, which are the glory of Concord, and at any season of the year may be seen scrambling up and down their rough bark. He has been well named "the upside down 
bird," for he is the only one who seems to prefer to run down a tree head-foremost. My little friend usually announces his presence by a cheerful "quank, quank," which always calls me to the window.

In 1901 two male nuthatches and one female were constant visitors to our tree. It is easy to distinguish the sexes, because the blue-gray plumage of the male is so much brighter and handsomer than that of the female. The difference in the head-dress is marked. The male wears a fine black velvet cap which runs over the back of his neck like a fireman's helmet, while the female is attired in what looks to be one of her husband's dingy and discarded chapeaux. The nuthatches are very tame, and every now and then I hear the clatter of their high-heeled shoon on the window-sill, for they delight to feed on the sunflower seed which I put there for the chickadees. Chopped peanuts, if one can afford the extravagance, are another dainty which they enjoy. The little creatures have often eaten from my hand under the raised window.

Next to the nuthatch, the downy woodpecker is the bird most likely to be seen on our winter trees in town. Almost everyone is familiar with his striped and mottled coat of black and white. The male bird wears a red band in his cap. It is interesting to see a 
woodpecker climb a tree. He hitches his way up, a jerk at a time, as if he were ascending the rounds of a ladder. The nuthatch, on the other hand, uses his legs as if they were arms, and swings himself into any position, while the brown creeper corkscrews about a tree like a little mouse, with his body pressed flat against the bark.

The brown creeper is less likely to be seen than either of the other birds, not only because he is rarer, but also on account of his protective coloring. His brown body blends with the tree trunk, and unless you see him move or catch a glimpse of his fluffy brown and white speckled breast he might pass for an excrescence on the bark. He usually begins at the base of a tree, works his way rapidly upward in a spiral, and then flies to another tree without losing a moment. His long, arched, black bill works unerringly, while his stiff tail is clamped to the bark as with a spring. It holds him like the spikes in the lineman's boots, leaving his claws free to cling.

Of all our winter birds the chickadee is probably the most popular. $\mathrm{He}$ is abundant in the evergreen woods and is a frequent visitor to those dooryards where he has once found food. Although particularly fond of sunflower seeds, the chickadees will eat 
suet almost as well as the nuthatches. The chickadee's note is the most cheery sound we hear in winter. Well might Emerson admire "this scrap of valor" who

"just for play

"Fronts the north wind in waistcoat gray."

No wonder the poet inquires

"What fire burns in that little chest, So frolic, stout and self-possest?"

There is one good thing about the chickadee: If he comes at all, he comes in flocks. I have seen a dozen of these black-throated, white-cheeked little midgets on my window-sill at one time. They would struggle for the sunflower seed, carry off a bit to a neighboring tree, and then fly back like black-headed bullets after more.

Although the four preceding species are all that I have ever found common about the house in the winter, there are other kinds occasionally seen. The hairy woodpecker has sometimes honored us with a call. Although his coloring is practically the same as that of the downy, his large size, equal in length to a robin, and his big head and beak easily distinguish him. His rattling cluck might almost be mis- 
taken for a robin's. The shrike, a handsome bird, now and then drives into our yards. If he would only confine his butchering to our British invaders, I should say, May his shadow never grow less! Unfortunately he likes a variety in his meat and attacks our native birds as well as the sparrows.

Anyone driving outside the town may see flocks of juncos or snowbirds, which come in October and remain until April. They always seem to me too dark to be associated with the snow. The entire upper part of their costume is a deep slate blue with the exception of the white outer tail feathers, which are conspicuous when they fly. The white snowbirds or buntings are less common, though farmers see them on the meadows, and travelers now and then report them from the roadside. They are an Arctic bird, drifting down here in our coldest weather, and their coming usually presages a storm. I recall one beautiful flock, as plump as pigeons, which I saw on Washington's birthday, 1896, near St. Paul's School. By a curious coincidence I saw a similar flock in almost the same spot on that very day, nine years later.

The crossbills are registered as winter birds, though the only pair I ever saw were in a village street in Wakefield one August afternoon. The rosy pine 
grosbeaks, a big, handsome, stupid bird, were quite common here in 1899 and again in 1903, both in town and out. Another pretty bird with a chestnut crown and a slightly reddish tinge to his coat is the tree-sparrow, which I have found at Sewall's Falls and when snow-shoeing at Walker's Island. Blue jays often hang about the farm-yards in cold weather, but they are too wary to venture into town. I set up a shook of corn in our dooryard one winter, hoping to attract them, but they were not to be caught by the golden bait.

It is said that the crows in mid-winter go to the seashore to feed on the refuse of the waves, but I almost always hear them in February. Of all our Nature lovers, Frank Bolles is the one who has most appreciated this knowing bird. He gave the name of Crowlands to his summer home at Chocorua Lake, and there under the shadow of New Hampshire's most picturesque mountain he studied their dusky legions. For a glorification of the crow, read his "Chocorua's Tenants."

December 6, 1905. 


\section{SHRIKE VS. SPARROW.}

Just before Christmas I noticed in a local paper a communication from Laconia to the effect that the shrikes or butcher-birds had been causing considerable destruction among the English sparrows in that region. One gentleman had been feeding a flock of sparrows at his back door. Subsequently finding some of their carcasses impaled on rose and barberry bushes about the place, he had offered a reward of a dollar apiece for the first five dead bodies of the shrike species delivered into his hands.

As this sparrow-advocate is a lawyer, it might be presumptuous to call his attention to the statute forbidding the killing of any birds in our state except hawks, crows, game birds in their season and the sparrows aforesaid; but I would like to make a counter proposition. If any citizen of Laconia or any other place has shrikes to spare, I wish he would send them down to our back yard where I would cheerfully furnish the birds with board and lodging. I am not certain that I would not pay a bounty of a dollar apiece on all the shrikes who would take up their permanent abode on our premises. We have an 
acre, more or less, of English sparrows which spend their time fighting and carousing under our windows, and driving off their betters, the native birds; and nothing would give me greater pleasure than to see the pirate butcher-bird sail into these little guttersnipes.

The shrike has been compared to the robin in size, but although they are about the same length, ten inches, their build is entirely different. The robin is a bird of portly, aldermanic protuberance while the shrike is lean and muscular, in good fighting trim. He is a decidedly handsome bird, blue-gray above and white below, with black, white-blotched wings and tail and black velvet markings about the eye. The shrike is not in the least bashful. In fact, he is the only bird I have ever met who will stare you out of countenance. He impresses me with a certain sense of majesty and power as does the bald eagle, and I am not certain but he is quite as good a citizen. Nature made them both cannibals, doubtless for some good purpose.

To return to the English sparrow: If there is any created thing that does not need encouragement or protection, it is this foreign bully. He is capable of taking care of himself and as certain to propagate his species as is the potato bug or brown-tailed moth. 
The worst of it is that you cannot devise traps, poison or any other means for his extermination that will not affect some desirable bird. He appropriates every good thing to his own use. We have an excellent unfurnished tenement of one room, about the size of a child's head, under the eaves in the corner of the barn, which we would be glad to have occupied by any respectable family. It is in a very desirable neighborhood, immediately adjacent to some ancient cherry trees, an unkempt buckthorn hedge and a wild tangle of bushes and vines, just what the birds love. Every year a pair of bluebirds comes to investigate, but before I can effect a lease, the unspeakable sparrows begin to move in their feather beds whereon they raise about three broods a year.

The sparrow has some wit: I will not deny that. This winter I poured some melted grease on a tree in order to attract the nuthatches. The nuthatches came, but the sparrows soon found them out. At first the nuisances played the part of the dog in the manger. and when they could not knock the nuthatches off the tree they contented themselves with flocking about its base and making insulting remarks. The sparrows then tried to climb the tree by sticking their toenails into the bark. They would get up about a foot be- 
fore tumbling back. At last they hit upon an expedient which I fear will prove successful. One of them flew against the tree, keeping his wings vibrating like a humming-bird's, and he was actually able to do this long enough to pick out a mouthful of the hard fat. They are all learning the trick now.

Ernest Seton-Thompson in his charming story of Biddy and Randy tells of an English sparrow who learned to sing like a canary by being brought up in a bird shop. Perhaps my experiment in providing for the nuthatches will result in the evolution of a new species of sparrow with the wings of a humming-bird and the claws and tail of a woodpecker. But, however the breed improves, I fear it will always retain its odious disposition and its "get there" propensities.

January 4, 1902. 


\section{LIST OF BIRDS ABOUT CONCORD.}

The following birds (110) have been observed about Concord and its immediate neighborhood by Frances M. Abbott. The two dates usually indicate the eariiest and latest time of year that the bird was seen. Occasionally two dates are given to show different localities. In a few cases, the second locality is out of town. For convenience of the amateur student, the birds have been arranged in the order of their appearance, rather than by species.

\section{MARCH BIRDS, 7.}

Bluebird. Memorial Hospital, March 6, 1903; Ferrin's Ledge, October 29, 1901.

Song Sparrow. The Intervales, March 13, 1902; Dustin's Island, November 5, 1902.

Robin. Old Cemetery, March 15, 1902; Golf Links, November 5, 1902.

Flicker. Our Garden, March 20, 1903; Appletown, September $21,1902$.

Goldfinch. Old Cemetery, March 23, 1902; Epsom, November 4, 1903.

Meadowlark. The Intervales, March 26, 1903; Bow Mills, October 7, 1901.

Redwinged Blackbird. Northern Railroad track, March 29, 1905; Sugar Ball, June 4, 1906. 
APRIL BIRDS, 20.

Purple Finch. Our Garden, April 6, 1903; Four-Gate Lane, July 2, 1899.

Chipping Sparrow. Our Garden, April 6, 1903; White Park, August 18, 1896.

Fox Sparrow. Our Garden, April 9, 1905; Back Ponds, November 14, 1903.

Phœbe. Our Garden, April 10, 1905; Asquam House (Ashland), September 28, 1901.

Ruby-crowned Kinglet. Our Hedge, April 13, 1905; Our Larch, May 4, 1905.

Purple Grackle. Asylum Grounds, April 14, 1905; Blossom Hill, June 22, 1904.

Hermit Thrush. Our Garden, April 18, 1904; Stark Place, Dunbarton, April 26, 1905; Rattlesnake Hill, October 26, 1905.

Palm Warbler. Snowshoe Club, April 19, 1902; Our Garden, May 4, 1905.

Vesper Sparrow. Near Little Pond, April 19, 1902; Knowlton Hill (Boscawen), July 13, 1903.

Bald Eagle. Back Ponds, April 20, 1902; Garvin's Falls, August 19, 1900.

Marsh Hawk. Little Pond, April 22, 1904; Marlboro, September 8, 1900.

White-throated Sparrow. Back Yard, April 22, 1903; The Plains, October 22, 1900.

Cedar Waxwing. Our Garden, April 22, 1904; Celia Thaxter's Cottage, Appledore, September 9, 1897; Our Garden, October 2, 1905. 
Tree Swallow. Dunbarton Road, April 26, 1905; Birchdale Road, June 12, 1899.

Myrtle Warbler. Our Elm, April 27, 1905; Back Yard, October 19, 1902.

Barn Swallow. Iron-Works Road, April 26, 1904; Garvin Hill, July 4, 1900.

Kingfisher. Back Ponds, April 27, 1896; Rose Bowl, October $2,1902$.

Black and White Warbler. Orchid Brook Road, April 30, 1905; Rattlesnake Hill, September 19, 1900.

Sparrow Hawk. Dunbarton Center, April 30, 1905; Eliot, Maine, September 27, 1904.

Least Flycatcher. Our Hedge, April 30, 1904; Sugar Ball, June 4, 1906.

MAY BIRDS, 48.

Pine Warbler. Camp Weetamoo, May 1, 1900; White Park, May 24, 1905.

Purple Martin. North Pembroke, May 1, 1902; Garvin Hill, July 4, 1900.

Kingbird. Ferry Lane, May 3, 1905; Garvin Hill, July 4, 1900.

Yellow Warbler. Ferry Lane, May 3, 1905; Marlboro, September 7, 1900.

Chewink. Our Garden, May 3, 1905; Birchdale, October 7, 1905.

Chimney Swift. Over the House, May 3, 1903; Christian Shore, June 19, 1899.

White-crowned Sparrow. Our Garden, May 4, 1905; Ferry Lane, May 15, 1906. 
Blackburnian Warbler. Our Garden, May 4, 1905; District Number Five (back of Long Pond), May 21, 1904.

Ovenbird. Our Garden, May 4, 1905; Rattlesnake Hill, October 19, 1900 .

Nashville Warbler. Our Garden, May 4, 1905; Camp Weetamoo, May 16, 1903.

Veery. Pearl Street, May 4, 1905; Saltmarsh's, Long Pond, July 5, 1901.

Brown Thrasher. Pineholm, May 5, 1905; Tyler's Bridge (Contoocook), August 18, 1905.

Catbird. Pineholm, May 5, 1905; Loudon Road, October 2, 1905.

Spotted Sandpiper. Pineholm, May 5, 1905; near Northern Railroad Track, August 30, 1897.

Black-throated Blue Warbler. Little Pond Road, May 6, 1902; Our Hedge, August 9, 1904.

Baltimore Oriole. Near Little Pond, May 6, 1902; Garvin's Falls, May 12, 1900.

Broad-winged Hawk. Shattuck Road, May 7, 1901.

Black-throated Green Warbler. Little Pond Road, May 7, 1901; Sandwich, September 19, 1901.

Warbling Vireo. Bradley Park, May 7, 1905; The Mountain, East Concord, May 14, 1906.

Redstart. Blossom Hill, May 7, 1905; Mountain Lane, September 28, 1902.

Humming-bird. Our Garden, May 8, 1905; Sandwich, September 21, 1901.

Chestnut-sided Warbler. General Patterson's, May 9, 1900; Passaconaway Club, August 3, 1903.

Parula Warbler. General Patterson's, May 9, 1900; Our Garden, September 22, 1902. 
Wilson's Warbler. Our Garden, May 9, 1905; Birchdale, May 11, 1905.

Rose-breasted Grosbeak. Our Elms, May 9, 1905; Lamprey Place, August 12, 1900.

Maryland Yellow-throat. Birchdale, May 11, 1905; Rattlesnake Hill, October 26, 1905.

Bobolink. Clinton Street, May 11, 1905; beyond Birchdale, August 15, 1903. (Flock in autumn coloring.)

White-eyed Vireo. Sewall's Falls, May 12, 1902.

Solitary Sandpiper. Ferry Lane, May 12, 1904.

Yellow-throated Vireo. Back Yard, May 12, 1901; Pumping Station, May 23, 1903.

Wood Pewee. Bow Road, May 12, 1900; Back Yard, October 12, 1903.

Black-poll Warbler. Back Ponds, May 13, 1900; Rollins

Park, November 3, 1896.

Magnolia Warbler. Pumping Station, May 14, 1905; Our Garden, October 3, 1904.

Field Sparrow. Rattlesnake Hill, May 14, 1900; Our Garden, September 21, 1902.

Solitary Vireo. Top of Rattlesnake, May 14, 1900; Ferry Lane, May 31, 1901.

Indigo-Bunting. Near Rollins Park, May 16, 1903; Meeting-house Hill, Bow, August 15, 1903.

Wood Thrush. Franklin Street Swamp (near Auburn), May 17, 1900; Pineholm, August 18, 1902.

Red-eyed Vireo. Our Trees, May 17, 1903; Batchelder's Mills (East Concord), June 16, 1901 (nest with four eggs); Robinson Road (Bow), August 19, 1900.

Canadian Warbler. Pumping Station, May 17, 1905; Back Yard, August 23, 1903. 
Tennessee Warbler. Our Hedge, May 17, 1905.

Yellow Palm Warbler. Fort Eddy, May 17, 1904; Sandwich, September 22, 1901.

Scarlet Tanager. Rattlesnake Hill, May 18, 1896; Carter District (Number Four), July 22, 1901.

Olive-backed Thrush. Camp Weetamoo, May 29, 1905; Holden's Point, Long Pond, October 15, 1903.

Nighthawk. Over the House, May 22, 1903; Carter District, August 21, 1900.

Orchard Oriole. Fort Eddy, May 24, 1903; Our Garden, May 31, 1903.

Bay-breasted Warbler. Pearl Street, May 26, 1905.

Great Crested Flycatcher. Near Reservoir, May 26, 1902;

Rattlesnake Hill, September 11, 1902.

Black-billed Cuckoo. The Fan, May 26, 1901; Hathaway Inn, June 13, 1904; Our Garden, August 31, 1902.

\section{SEEN IN SUMMER, 17.}

Ruffed Grouse (Partridge), with two little chickens. Parsonage Hill, June 2, 1901; near Centennial Park, November 5, 1901.

Cowbird. Hall Street Meadows, June 4, 1905; near the

Countess of Rumford's, June 8, 1899.

Grasshopper Sparrow. Hall Street Meadows, June 4, 1905;

Kimball Tavern, Pembroke, October 1, 1905.

Savanna Sparrow. Hall Street Meadows, June 4, 1905.

Bank Swallow. Hall Street, June 4, 1905; Passaconaway

Club, August 3, 1903.

Summer Tanager. Batchelder's Mills, June 10, 1901. 
Cliff Swallow. Appletown, June 15, 1905.

Loggerhead Shrike. Noyes Street, June 21, 1901.

House Wren (pair, nest and young). Fort Eddy, June 22, 1902.

Whippoorwill. Saltmarsh dooryard (Long Pond), July 9, 1902; Country Club, July 27, 1902.

Little Blue Heron. Portsmouth Bridge (Bow Junction), July 27, 1902.

Screech Owl (four young ones). Joseph B. Walker's Trees, August 2, 1905.

Great Blue Heron. Passaconaway Club, August 3, 1903.

American Bittern. Camp Wobegon, Long Pond, August 5, 1905.

Prairie Horned Lark. Christian Lane, August 5, 1900.

Worm-eating Warbler. Our Hedge, August 7, 8, 1904.

Little Green Heron. Rose Bowl, August 10, 1900.

AUTUMN MIGRANTS, 6.

Northern Water-Thrush. Contoocook Park, September 2, 1903; Our Garden, October 3, 1903.

Rusty Blackbird. Kimball Tavern, Pembroke, October 1, 1905; Rollins Park, October 4, 1905.

Yellow-bellied Sapsucker. Shattuck Road, October 6, 1904. American Pipit (big flock). Walker's Island, October 17, 1904.

Horned Lark (big flock). Walker's Island, October 17, 1904; near Free Bridge, March 24, 1906.

Golden-crowned Kinglet. Rattlesnake Hill, October 26, 1905; Our Hedge, April 23, 1903. 
WINTER AND RESIDENT BIRDS, 12.

White-breasted Nuthatch. Appletown, September 21, 1902; Our Arbor Vitæ, March 14, 1904.

Junco. Snow's Pond, October 3, 1903; Blossom Hill, May 28, 1905 (very late); nesting on Catamount, Pittsfield, July 9, 1904.

Downy Woodpecker. Memorial Hospital, October 9, 1901; Country Club, June 4, 1898.

Pine Grosbeak. Asylum Grounds, Long Pond, October 20, 1903; St. Paul's School, February 13, 1904.

Tree Sparrow. Hopkinton Road, November 2, 1903; Sewall's Falls, February 17, 1904.

Crow. Contoocook River, October 15, 1900; Sewall's Falls, February 17, 1904.

Hairy Woodpecker. Our Garden, November 11, 1897; Our Trees, December 21, 1902.

Brown Creeper. Our Trees, November-February, 1903-'04; Blossom Hill, April 22, 1906.

Northern Shrike. Blossom Hill, November 15, 1905; Our Hedge, January 11, 1898.

Blue Jay. St. Paul's School, December 31, 1902; The Reservoir, June 2, 1906.

Snow Bunting. Near Mrs. Eddy's, February 22, 1896; Break O' Day, March 24, 1906.

Chickadee. Walker's Island, March 8, 1900; General McClary Place, Epsom, September 25, 1899. 


\section{SEEN BY OTHER OBSERVERS, 91.}

The writer is indebted to Mr. William W. Flint of St. Paul's School, who has catalogued 120 birds; to Mr. L. J. Rundlett, superintendent of the Concord schools, to Gen. Frank Battles, and to Mr. Frank S. Moulton, three accomplished sportsmen, who have added a list of 50 game birds and birds of prey; to Mrs. Elizabeth Sylvester Clough of East Concord and to other competent observers for 91 additions to the list of birds seen in the township of Concord. The number of species so far reported is 201, which doubtless can be increased by further study.

Bittern:

Least.

Bob White.

Chat:

Coot.

Yellow-breasted.

Crane.

Crossbill:

Red,

White-winged.

Crow:

Fish.

Cuckoo:

Yellow-billed.
Dove:

Mourning.

Duck:

Black,

Black Scoter,

Buffle Head,

Gadwall,

Golden-eye,

Lesser Scaup,

Mallard,

Pin-tail,

Red Head,

Ring-necked, 
Duck (continued) :

Shoveller,

Velvet Scoter,

Widgeon,

Wood.

Flycatcher:

Acadian,

Alder,

Olive-sided.

Goose:

Canada.

Goshawk.

Grackle:

Bronzed.

Grebe:

'Pied-billed,

Ring-necked.

Grosbeak:

Evening.

Gull:

Bonaparte's,

Herring.

Hawk:

Cooper's,

Pigeon,

Red-shouldered,

Red-tailed,

Sharp-shinned.

Jay:

Canada.
Longspur:

Lapland.

Loon.

Merganser:

Goosander,

Hooded,

Red-headed.

Nuthatch:

Red-breasted.

Osprey.

Owl:

Acadian,

Barred,

Great Horned,

Hawk,

Long-eared,

Richardson's,

Short-eared,

Snowy.

Oyster-catcher.

Pigeon:

Passenger.

Plover:

Black-bellied,

Golden,

Kildeer,

Ring Neck,

Ruddy.

Rail:

Carolina, 
Rail (continued) :

King,

Virginia.

Redpoll.

Sandpiper :

Bartramian,

Least,

Pectoral,

Red Back,

Semi-palmated.

Turnstone.

Snipe:

Wilson's.

Sparrow:

Swamp.

Teal:

Blue-winged,

Green-winged.

Thrush:

Gray-cheeked.
Warbler:

Cape May,

Hooded,

Mourning,

Prairie.

Water-thrush:

Louisiana.

Woodcock.

Woodpecker:

Pileated,

Red-headed.

Wren:

Short-billed Marsh,

Winter.

Willet.

Yellow-legs:

Greater,

Lesser. 


\section{ALPHABETICAL INDEX OF BIRDS ABOUT CONCORD, 201.}

Bittern:

American .....66 65

Least .......66 67

Blackbird:

Red-winged ....59

Rusty .......65

Blackbirds, see Grackles.

Bluebird ........ 59

Bobolink ........66 63

Bob White .......6 67

Bunting:

Snow .......66 66

Catbird ........6.62

Chat:

Yellow-breasted... 67 Chebec:

See Least Flycatcher.

Chewink .........66 61

Chickadee ........66 66

Coot ..........6 67

Cowbird .........6.64

Crane ...........6 67

Creeper:

Brown .......66 66

Crossbill:

Red .........66 67

White-winged ... 67
Crow:

Common ......66 66

Fish ........667

Cuckoo:

Black-billed ..... 64

Yellow-billed .... 67

Dove:

Mourning ....66 67 Duck:

Black ........6 67

Black Scoter.... 67

Buffle Head..... 67

Gadwall .......667

Golden-eye ....667

Lesser Scaup ....67 67

Mallard ......66 67

Pin-tail .......66 67

Red Head ......6 67

Ring-necked ....667

Shoveller ......66 68

Velvet Scoter .... 68

Widgeon ......6 68

Wood ........6 68

Eagle:

Bald ........6 60

Finch:

Purple .......60 
Flicker .......... 59

Flycatcher:

Acadian .......6 68

Alder ........66 68

Great Crested.... 64

Least ........66 61

Olive-sided .....6 68

Goldfinch ......... 59

Goose:

Canada ........6 68

Goshawk ........ 68

Grackle:

Purple .......6 60

Bronzed .......66 68

Grebe:

Pied-billed ...... 68

Red-necked .....668 Grosbeak:

Evening .......66 68

Pine .........6 66

Rose-breasted .... 63 Grouse:

Ruffed ........6 64 Gull:

Bonaparte's ..... 68

Herring .......6 68 Hawk:

Broad-winged .... 62

Cooper's ........68 68
Hawk (continued):

Marsh ........6 60

Pigeon .........6 68

Red-shouldered .. 68

Red-tailed .....6 68

Sparrow .......6 61

Sharp-shined ...6 68 Heron:

Great Blue......65

Little Blue...... 65

Little Green..... 65

Humming-bird ...... 62

Indigo-bird .......66 63 Jay:

Blue ........66 66

Canada .........6 68

Junco ........... 66

Kingbird ........6 61

Kingfisher ........6 61

Kinglet:

Golden-crowned... 65

Ruby-crowned ... 60 Lark:

Horned .......6 65

Prairie Horned... 65 Longspur:

Lapland ......66 68 Loon:

Common ......66 68 
Martin:

Purple .......66 61

Meadowlark ....... 59

Merganser:

Goosander ......66 68

Hooded .......66 68

Red-headed .....6 68

Nighthawk ........ 64

Nuthatch:

Red-breasted ..... 68

White-breasted ..66 Oriole:

Baltimore ......6 62

Orchard ........6 64

Osprey ..........6 68

Ovenbird ..........6 62

Owl:

Acadian .......66 68

Barred ........66 68

Great Horned.... 68

Hawk ......... 68

Long-eared .....66 68

Richardson's ...66 68

Screech .......6 65

Short-eared ...... 68

Snowy .......66 68

Oyster-catcher ......668

Partridge:

See Grouse, Ruffed.
Pewee:

Wood .........6 63

Phœbe ........... 60

Pigeon:

Passenger .....66 68 Pipit:

American .....66 65 Plover:

Black-bellied ..... 68

Golden ........6 68

Kildeer ........6 68

Ring Neck......6 68

Ruddy .......66 68 Rail:

Carolina .......6 68

King .........6 68

Virginia .......6 68

Redpoll ......... 69

Redstart .........6 62

Robin .......... 59

Sandpiper:

Bartramian .....6 69

Least .........6 69

Pectoral ........69 69

Red Back....... 69

Semi-palmated ... 69

Solitary .......6 63

Spotted .......6 62

Turnstone ........6 69 
Sapsucker:

Yellow-bellied ... 65 Shrike,

Loggerhead ....65 65

Northern .......66 66 Snipe:

Wilson's ......6 69 Sparrow:

Chipping ......6 60

Field ..........63 63

Fox .......... 60

Grasshopper ..... 64

Savanna ....... 64

Song ......... 59

Swamp ....... 69

Tree ........66 66

Vesper .......66 60

White-crowned ... 61

White-throated .. 60 Swallow:

Bank .......... 64

Barn .........6 61

Cliff ........6.65

Tree .........6 61 Swift:

Chimney ......6 61 Tanager:

Scarlet ........6 64

Summer .......6 64
Teal:

Blue-winged ....6 69

Green-winged ...6 69 Thrasher:

Brown .......6 62

Thrush:

Gray-cheeked ...6 69

Hermit ........6 60

Olive-backed ....6 64

Wood .........6 63

Veery ...........6 62

Vireo:

Red-eyed ......66 63

Solitary .......6 63

Warbling .......6 62

White-eyed .....66 63

Yellow-throated... 63 Warbler:

Bay-breasted .... 64

Blackburnian .... 62

Black and White. 61

Black-poll .....66 63

Black-throated Blue ........6 62

Black-throated

Green .......6 62

Canadian ......66 63

Cape May......6.69

Chestnut-sided ... 62 
Warbler (continued):

Hooded ........ 69

Magnolia ......6 63

Mourning ...... 69

Myrtle (yellowrumped) ....66 61

Nashville ....... 62

Palm (yellow redpoll) ........6 60

Parula (blue yellow-backed ) ...662

Pine .........6 61

Prairie ........6 69

Tennessee ......664

Wilson's .......66 63

Worm-eating ....65

Yellow ........6 61

Yellow Palm..... 64

Water-thrush:

Northern ......6 65

Louisiana ......6 69
Waxwing ......... 60

Whippoorwill ......6 65

Woodcock ........ 69

Woodpecker:

Downy ........66 66

Golden-winged

(see Flicker),

Hairy .........66 66

Pileated ........69 69

Red-headed .....6 69

Wren:

House ........66 65

Short-billed Marsh 69

Winter ........69 69

Willet ...........6 69

Yellow-legs:

Greater .......69 69

Lesser .......6 69

Yellow-throat:

Maryland .....66 63 


\section{CHARACTERISTIC FLOWERS OF CONCORD.}

It does no harm to tell where you see a bird, for you never know if you will find him there again; but the writer has hesitated about disclosing the locality of favorite wild flowers. The flower is defenseless against friends and foes alike, and if it were not that Nature has provided several means for the distribution of seeds, so that the embryonic plant can literally take to itself wings and flee away, more species would be exterminated than already have been. It is such a temptation to seize upon beauty when one finds it growing in profusion, that the person of æsthetic tastes should remember that wild flowers are never so lovely as in their native environment. Nearly all the more delicate kinds are ineffective for house decoration, which can best be carried out by those of robust growth like the hobble-bush, daisies, wild carrot, meadow lilies, Joe-Pye-weed, asters, goldenrod and the like.

The young student, as well as Nature lover, should take to heart Emerson's lines: 
"Hast thou named all the birds without a gun? Loved the wood-rose, and left it on its stalk? At rich men's tables eaten bread and pulse?

O, be my friend, and teach me to be thine!"

Notwithstanding the encroachments of the city and the slaughter of the woods, the township of Concord is still rich in wild flowers, and especially favored in certain varieties that are not common everywhere.

The study of Nature can be begun at any season of the year. Remember that it is always interesting out of doors. The trees are never more beautiful than in winter; and it is good to watch the swelling of the buds when the ground is deep with snow. Pussy willows can be found in February; perhaps earlier, if the sun is strong; but the first flower of spring is undoubtedly the odoriferous skunk cabbage which is all well enough if you let it alone. There is something inspiring about the vivid green of this sturdy spike, and, though as a decorative blossom it is doubtless a failure, its minute flowers under their purplish sheath give a promise of good things coming.

When it comes to attractive blossoms, the hepatica and the trailing arbutus are probably first in season about here. They may be found in March, under 
exceptionally favorable circumstances, but in April you are sure of them. In fact, April is so much the month of the Mayflower that I always wondered why its name was bestowed, because by Mayday the flowers are over-ripe. The Mayflower seems to grow everywhere in the woods about town, and, notwithstanding the carelessness of people in pulling up its trailing stems, which should always be cut, never torn, its abundance is not appreciably diminished. Certain localities in Bow, as in former years the Plains, are noted for the size and pinkness of its blossoms. The hepatica or liverwort, whose delicate lavender or bluish flowers would be found shivering in their furry coats, if they did not grow close to the ground, is much less common than the arbutus, but it may be found sporadically in various localities like the West Concord woods and the Sewall's Falls region.

Other characteristic flowers of April are the bloodroot, whose evanescent whiteness stars the grass at Paradise, and the dog-tooth violet, whose delicate yellow bells droop under the Bluffs and by many another spring marsh. Whoever sees the beautiful, mottled leaves of the latter must appreciate John Burroughs' suggestion that it should be called the fawn lily. The Erythronium bears no relation to the violet, either in 
appearance or structure, but its leaves suggest the startled ears of a fawn while their spots mimic his dappled hide. The shad-bush too must not be forgotten, for its white bloom splashes the April woods in all parts of the town. The casual observer might think its multitudinous blossoms belong to the wild cherry, but the long, narrow petals easily distinguish it.

In May there is an embarrassment of riches. In looking over my records I find, "Christian Shore, May 14, 1898, a garden of violets, anemones, bellworts, dwarf ginseng, and shad-bush." The very names recall the ecstasy of those days when the feathery spires of the foam flower rise in Paradise, the painted trilliums gem the swamps of the Bog Road near the Contoocook, the marsh marigolds gild the region of Broad Cove and the foot of Dimond Hill, the ladies' slippers hang their pink pouches in the woods below Weetamoo, and the bluets enamel the meadows about Ferry Lane and the Fan. Strawberry blossoms and the yellow cinquefoil are everywhere in May, but the flower of this month that seems peculiarly characteristic of Concord is the fringed polygala or bird-on-thewing. The richness of its crimson-violet petals is hardly inferior to that of some of the smaller orchids, 
and its beauty is equalled by its abundance. It grows in masses along the Little Pond Road, is plentiful near Garvin's Falls, and glows among the star-flowers, the bunch-berries and the clintonias, which carpet nearly all our woods.

By June the more delicate of the spring flowers have passed. Vegetation is at its crescendo. The meadows are sweet with the ripening grass; the maidenhair ferns have unfolded their exquisite fronds of tender green in Paradise; daisies and buttercups bespangle the fields; but the wild rose, the month's birthright, is rare about Concord. The flower of June in this region is the lupine. Acres of this leguminous plant grow on the Plains, and it may be found by the sandy roadsides in Penacook, East Concord and Bow Junction. It is good to see enough of anything so beautiful. In the words of a Concord physician :*

"The lupine's blue, as it greets the eye, Vies with the blue of the summer sky, Which shuts us in to a world of care Which the lupine's beauty helps us bear."

Although blue is the prevailing color of the lupine, the blossoms are occasionally a pinkish-lavender or even a pure white. There is a certain spot on the *Dr. A. P. Chesley. 
road to Garvin Hill where I go every summer to find the blanched specimens. There is another flower associated with the Plains, the little Hudsonia ericoides, allied to the poverty grass of Cape Cod. On June 7, 1905 , one of those raw days which sometimes depress the month with a temperature of 45 degrees, we were taking a chilly drive across the Plains when we suddenly came upon a mass of the vivid yellow of the Hudsonia, which

"Like the great eye of Heaven shinëd bright, And made a sunshine in the shady place."

Its gold fairly penetrated the gray of the sky, and we felt warmer under our fur robes.

Pink seems so appropriate to June that we must not forget the mountain laurel, which grows on the Bow hills, and the smaller and less lovely species, known as lambkill, which is common among the pines of the Plains. The exquisite sea-shell tint of the azalea, sometimes called river pink, is becoming so rare, alas! that I dare not specify on what parts of the Contoocook and the Merrimack it may be found.

A rare and curious flower of this month, which honors us by making its home in Concord, is the pitcher plant, whose hollow leaves are admired quite 
as much as its singular blossom of dull rose. Its favorite dwelling-place is amid the sphagnum, the moss in which cranberries grow, along the shores of Snow's Pond in East Concord. It is most difficult to reach, either by boots or boats, but it is worth risking a wetting to gather it. Years ago a girl wrote of these pitchers :

We crossed a brook on a slippery log, And fished them out of a cranberry bog, And then leaped back again like a frog, And started home at a lively jog, Closely followed by our dog, And set our neighbors and friends To whom we gave them, all a-gog.

With the heats of July the yellow lilies light up the fields and the red lilies burn in the wood, the tall meadow rue rises like a fountain of spray along the banks of the Contoocook, the hawkweeds and the loosestrifes draw the eye by their abundance, the water lilies open their chalices, the pickerel weed and the arrowhead fringe the ponds with blue and white, the purple-flowering raspberry unfolds its magentarose petals over its rank, five-lobed leaves along the Shattuck Road; but the distinctive flowers of this month to my mind are the modest spikes and clus- 
ters of the pyrola and the pipsissewa. We have several species of the pyrola, and the large-leaved ones are abundant in all our woods. At a distance this plant suggests a wild lily of the valley. It has a sweet odor, and the flowers with their protruding styles are more curiously wrought than lily bells. In driving about Long Pond and Turkey Pond, or in Districts Number Four and Five, I am always glad to catch the white gleam of the pyrola.

The pipsissewa with its shining, evergreen leaves and delicate discs studded with violet anthers (the blossoms have been likened to a passion flower on a small scale) is more beautiful in some respects even than the pyrola. Unfortunately it is not so common, probably because our grandmothers considered it a fine, medicinal "yarb." Its flowering season is brief, but I always look for it about the tenth of July in the woods at Christian Shore or below Camp Weetamoo or in various parts of West Concord.

In August there is a riot of vegetation, and yet one may now and then detect the subtle signs of the coming fall. The goldenrod, which began in July, is now obtrusive, and the asters are becoming conspicuous. The shores of Turkey Pond are rosy with the marsh St. Johnswort, and the fragrant, chocolate-colored 
wild bean twists and twines about Mountain Lane and the road to Pottertown. All the stout, showy flowers are trying to see which shall overtop its neighbor. Meadow-sweet and hardhack, the tick-trefoils and sticktights, sunflowers and elecampane (the latter's thick, mucilaginous leaves are rather rare about here), milkweeds, turtle-head and Joe-Pye-weed are striving for precedence, while the clematis and the wild balsamapple make glad the waste places. But the crown of the year, our characteristic August flower, is none of these. It is the gorgeous cardinal lobelia.

No native flower can vie with the cardinal in vivid coloring. People in other places have waited years to see it. Happily it is rather abundant about Concord; but, luckily for its own protection, it stands with its feet in the water, and is not easily accessible from the dry land. The brooks and ponds about Birchdale are its favorite haunts, but its intense red spires flame around Batchelder's Mills, and occasionally are seen near the pin-cushion globes of the button-bush along other water-ways. One is not likely to forget the first sight of the cardinal's blinding beauty. I think of that August afternoon when a party of us drove out to Birchdale, and the ecstatic shout that went up, 
"The cardinals! the cardinals!" when we saw hundreds of the spires burning in the wet meadow.

September is the month of purple and gold. Asters and goldenrod are everywhere and at first sight there seems little else except the summer survivals. Among those which have continued from August are the closed gentian whose deep, purplish blue "bottles" are reflected in the still waters of the Contoocook and in many another shady nook, and the brilliant fall dandelion, whose tall, wiry stems grow in such profusion about the pond at S. Paul's School. This striking yellow flower seems massed in this place; at least, I have never seen it elsewhere in Concord. The prettiest asters that we have are not purple, but white. Two rare varieties are the ericoides and the multiflorus, one with wand-like stems a foot long and the other a little bushy, heath-like plant; both are thickly powdered with white stars. These two species grow on the old road to Pembroke, half a mile or so below the Indian Carry where Hannah Dustin is supposed to have camped when she floated down the Merrimack with her grewsome trophies. The same varieties have also been found on the road from Batchelder's Mills leading across the Plains.

Despite the prevalence of the Compositce, there is 
one unobtrusive little flower that marks for me the month

"When the noons are sultry hot, And the nights are frosty cool."

When the September mists are rising, and the watery sunlight leaks through the dense foliage, having lost its power to warm,- -by the roadside or in the damp meadow I notice everywhere the faint, elusive fragrance and the stiff little spikes of the spiranthes or ladies' tresses. White as a nun, but erect as a soldier, this little orchid stands like a sentinel guarding the gates through which summer has passed and autumn is coming.

What is there left in October but the gorgeous foliage and the ripening harvest of the dying year? The goldenrods are mostly wraiths and the asters are hardly more than mists; the hawthorn shows its scarlet fruit and the black alder is studded with coral berries. Still, there are flowers. I have gathered violets in the mellow sunlight, and in 1898, on October 24, I found the pink, yellow-tipped blossoms of the pale corydalis in full bloom on Rattlesnake Hill. The rare flower of the month is undoubtedly the fringed gentian. 
"Then doth thy sweet and quiet eye Look through its fringes to the sky."

This lovely wanderer at one time lived in numbers in the Rowell meadow on the shores of Turtle Pond. In 1903 I found it as late as November 4 on Epsom Ridge. In 1897 and 1902 I marked it for the last week in September at Batchelder's Mills and on the Shaker Road. You would probably find it in none of these places, for it flees like a bird before the hunter.

But the flower of the month that sheds its spicy, aromatic fragrance everywhere is the witch hazel. It seems the very spirit of the autumn. It puts forth its delicate, yellow fingers in September, and on November 25, 1905, just a month before Christmas, I found it in full bloom on the Little Pond Road. How inspiring to see this shower of golden stars when skies are gray and the birds have flown. Is it Jupiter come to visit Danäe? There is nothing that equals its spicy scent, unless it be the sweet fern of the upland pastures mid the sun-dried summer grasses. There is virtue in you, witch hazel, Egyptian balm; and it is fitting that the earth should be wrapped in spicery to prepare it for its winding sheet of snow.

March 26, 1906. 


\section{THE ROYAL FAMILY OF ORCHIDS.}

It will surprise people who think of orchids as the rarest and most beautiful of tropical curiosities to learn that no less than twenty-five varieties of this royal tribe have been found growing wild in Concord. Of the eightythree families which comprise the recorded flora of our township, the Orchidaceae stand fourth in number of species. The first three are the Composito, numbering sixtythree species, the family which seems nearly universal in late summer, when goldenrod and asters prevail; the Rosaceae, thirtyfive species, which includes our favorite fruits and berries; and the Leguminosae, twentysix species, to which beans and clover and other butterfly blossoms belong.

With but three families larger than the Orchids, we have one which equals them in extent. This is the Ericaceae or Heaths, which comprises, to the unbotanical lover of Nature, such widely dissociated plants as the blueberry, the laurel, the Mayflower and the Indian pipe. The Ranunculacece or Buttercups come next with twentytwo species, and nothing else numbers over nineteen; in fact, most of our families could count their children on one hand. It must always 
be remembered that the list of five hundred and forty species at the end of this book is merely suggestive, not exhaustive; but perhaps it may be regarded as fairly representative.

It is pleasant to know that, not only are our orchids numerous as compared with the other flower families of Concord, but that we have, for a cold, Northern climate, a fair share of the number in the whole world. According to Britton and Brown, the latest and highest botanical authorities, about five thousand species of orchids are known to exist. To say that we have twentyfive of these or half of one per cent. ought to make us feel as rich as if we possessed a like share of the diamond fields of South Africa or of the art treasures of Europe.

It must not be supposed, however, that all our orchids are conspicuously beautiful. To those whose sole idea of an orchid means the gorgeous air plants with pink, crimson-flecked petals or white splashed with lavender or yellow mingled with brown, seen in the florists' windows of the big cities, some of our small orchids like the coral-root, the rattlesnake plantain, the twayblade or the ladies' tresses would seem too insignificant to be the humblest of poor relations. Yet to the student there is something fascinating 
about even the lowliest member of this wonderful family. In general structure the orchid resembles the lily; both have parallel-veined leaves and a sixparted perianth. The distinguishing feature of the orchid is the combined stamen and pistil called the column, and the curiously twisted petal known as the lip, which is sometimes beautifully variegated and often deeply fringed or spurred; this is designed to attract the bee or moth and secure the cross-fertilization on which the future of the plant depends.

Perhaps the most familiar of our orchids is the common lady's slipper, found in abundance in many of our woods. It is a beautiful flower, possibly less highly prized because we can bring home an armful instead of being forced to content ourselves with a single specimen. The town was once so fortunate as to possess a station for its near relative, Cypripedium spectabile or the showy lady's slipper, a superb flower whose pink and white variegated blossoms are quite equal to those of the tropical orchids. A few years ago this glorious creature grew on a hill slope at the Deacon Benjamin Farnum place at West Concord, now descended to his son, Charles H. Farnum. The writer well remembers the first visit of the Wild Flower Club to this place, June 22, 1896, and how 
some of the members fell on their knees before the orchid's fragrant beauty. This cypripedium grows to the height of two feet or more, and its lush, green foliage strongly suggests the false hellebore. It is ranked as the loveliest of its class in eastern North America. Alas! Ilium fuit! We no longer find it on that hill slope, but must look for its diminished and transplanted beauty in some of our gardens. We have still another cypripedium in Concord, the much prized yellow lady's slipper, but the man who tracked it to its remote haunt has wisely refused to divulge its whereabouts either for love or money.

West Concord, which our ancestors called Rattlesnake Plain, was once the favored home of other rare orchids. The exquisite arethusa, which Miss Wilkins has celebrated in one of her most spiritual "Understudies," formerly grew in the ravine near the old Priest Tenney place. Of late years it has been occasionally found in a meadow across the river.

The farms at West Concord, from the Farnum place northward, may be called two-story farms. Part of the land lies on a level with the street, then suddenly slopes down an abrupt bank to the interval bordering on the shifting Merrimack. It was in a boggy meadow on the lower story of one of these farms that 
the Wild Flower Club had one of its choicest preserves. It was the one place where we could go the latter half of June and be sure of finding quantities of the crimson calopogons and the fragrant, shell-pink pogonias. The meadow was fairly dotted with their slender stems, six to ten inches high, each topped with an exquisite, inch-wide blossom. The bog looked like a great green cushion set with jewelled stickpins. Here too we found the little fen orchis or twayblade, insignificant but interesting, as are all the members of this royal family; the ragged fringed orchis, which also grows at Martin's Cove; and several rare ferns. We had come to feel a proprietary right in our meadow, for it seemed a piece of waste land, except for its burden of beauty.

One summer we went as usual to admire our harvest -we were scrupulous about gathering too much of it; and to our horror and astonishment we found that there had been a change of owners; the bog had been drained, the soil turned over, our treasure house had been looted, and common, commercial grass was growing where once waved the fairy flags of the orchids. Calopogons and pogonias are still with us in other places, but they occur occasionally and incidentally. 
We nevermore expect to behold them in troops, as of yore in their native bog.

The passion for utilitarian improvements threatens all our natural beauty. To the botanist and birdlover a swamp is the most valuable part of a farm, and a wayside thicket is veritable riches. Let us heed the Call of the Wild. We cannot have birds if we cut down every bush by the road and railway track, and no cultivation will ever transform a bog or rocky ledge into anything half so inviting as its natural covering of chance-sown vegetation. Mown lawns are good to walk on, the same as concrete sidewalks, but the birds care as much for one as the other; while the passion for cutting and scraping bids fair to destroy all our woodsy dells with their wealth of lichens and creepers. Probably a new generation of Naturelovers must be educated before people learn that it is easy to trim and shave, but the old takes a long time to grow; and that a natural woods is more to be desired than a clipped park.

To return to our orchids: Much of the Turkey Pond region is still so inaccessible that it may be safe to mention it as the home of the habenarias. Here has been found the large. purple-fringed orchis, $H$. fimbriata, which blossoms in July, a spike at once so 
delicate and so majestic that it would seem that the most casual observer must pause before its noble beauty. It is not common, though it has been found in the Dell at Garvin Hill, at Snow's Pond, at Bull Meadow and several other places. Its smaller sister, the psycodes, which comes in August, is quite abundant. This has many more flowers crowded on the spike, but they are about half the size of the fimbriata and less beautiful with a rather pronounced fragrance. There is a certain stream that we have named Orchid Brook on account of this species. The woods near by is the home of the pretty little dalibarda, one of the Rosaceae, whose foliage suggests the violet. The two orchids just mentioned are called purple, when they are more nearly a pinkish lavender; but purple is a word of wide mis-application by the bird- and flowerchristeners.

The exquisite white-fringed orchis, $H$. blephariglottis, has been found in a remote jungle on the western side of Big Turkey, but ' $t$ is a parlous journey thither. The writer remembers to this day the damp heat of that August afternoon, the stings of insects and the irritation of minute crawlers, the wild scramble through the underbrush and the slappings and switchings from obdurate bushes, the stumbling over 
treacherous hummocks and through quaking bogs before the snowy prize was captured and borne away in triumph.

The Habenaria genus is the largest in our group of Concord orchids, numbering ten out of the twentyfive species. While the three previously mentioned are probably the most beautiful of the genus, for the exquisite ciliaris or yellow-fringed has not yet been located here, there is another one, the orbiculata, deserving of special mention. That and the Hookeri are occasionally found in our woods. The orbiculata has large, round leaves, often the size of a tea-plate, spread flat on the ground, and a spike of from fifteen to twenty flowers of waxy, greenish white. In 1898 the writer saw it in perfection at the Adirondack Reserve, a great tract of land which includes the Upper and Lower $\mathrm{Au}$ Sable Lakes. Its tall spikes, often more than two feet high, with their curiously wrought flowers, which look as if carved out of cucumber, were one of the most striking features of that beautiful natural park.

The writer cannot close this chapter without another plea for the preservation of the rare wild flowers. Not only have they been sacrificed to ploughing and building in the march of progress, but in many cases 
their beauty has proved their own destruction. We are told that the brilliant butterfly-weed or orange milk-weed once grew in the Gully leading to the Plains, but it long ago sought a more secluded retreat, and is now rarely found about Concord except in gardens. At Three-Mile Island in Lake Winnepesaukee, the summer camp of the Appalachian Mountain Club, all the wild flowers are jealously guarded, and not a shrub can be cut without permission. In July, 1905, the writer found the small green orchid, Microstylis ophioglossoides, at Three-Mile and also at Ossipee Park; but when she inquired the exact location of the ram's-head orchid, Cypripedium arietinum, whose delicate beauty might attract the flower gatherer, she was told that the single patch of it on Three-Mile was carefully guarded. She was permitted just one look at the sacred precincts-under escort; and saw about twenty dried seed-vessels, for the flower blooms in May.

Most of us have to learn consideration through losses. The writer confesses with shame that she once filled a rose bowl with calopogons and pogonias, just as a parlor decoration; but in 1899 when she saw the little northern bog orchis, Habenaria obtusata, on the North Woodstock path near the summit of Moosilauke, 
she was so glad to meet a member of the royal family on that height, that she made obeisance and passed on, leaving the little sentinel to wait the coming of some other friend.

April 26, 1906. 


\section{THE SEED HARVEST OF RATTLESNAKE}

\section{HILL.}

There were ten of us, and the day was Saturday, the 14th of October, the fairest of this wonderful month. We went by way of the park at the foot of the pond, because that ascent is the most gradual. We passed by the foundation of the new school-house on the site of the old Rumford garrison, and in going through the woods by the brookside somebody discovered the celluloid-red berries of the spice-bush. This was a find indeed, for the shrub is rare about town, and but one of our party had ever seen the tiny, honey-yellow flowers which come the last of March. It was Mrs. E. who braved the discomforts of the melting snow last spring, and brought home from this very spot leafless branches with their whorls of flower buds. While we were gathering the spice berries a flock of goldfinches in autumn coloring settled near by. There was not a trace of yellow in their dress, but the warm brown of their coats and the black and white of their wing bars gave them a jaunty appearance.

In gathering the vari-colored leaves with which the woods abounded the youngest of our party found a spray of the maple-leaved viburnum with a terminal 
cluster of deep blue berries, which had the bloom and color of the grape. The leaves of the Indian cucumber were quite withered, but one stalk supported a large dark berry which seemed to bear as little relation to the yellowish green blossom as do the long pods of the dogbane to the delicate pink bells which produce them. We did not happen on this trip to find any of the indigo blue clusters of the cat-brier, which in June has good reason to be called the carrion flower, but the writer has seen them this month on Oak Hill and by the Contoocook River. Amid all the blue berries of the fall, these are the ones most deeply, darkly, beautifully blue.

Beside the path grew the trailing vine of the hog peanut whose small brownish or blackened pods at once proclaim it as belonging to the tribe of Leguminosae, otherwise the Pea and Bean family. The familiar checkerberry and partridge berry showed their scarlet fruit, and we found some spotted berries of the Maianthemum Canadense, whose conspicuous abundance every spring should have earned it some English name.

The delicate yellow ribbons of the witch hazel are about as welcome a sight as the declining year can show. We found many branches with nuts on them, 
but none so heavily loaded as were those on Meetinghouse Hill in Bow, which the writer visited a week ago. It is good fun to keep the hazel boughs in a warm room for the sake of hearing the drying nuts pop open. They explode with a erack, sending the black seeds up to the ceiling or across the room. Thoreau used to gather them every fall for this purpose.

As we came out to the Fiske pasture on the northern slope of the hill we saw that it was one of those rare blue days when the horizon is rimmed with mountains, each distinct as ships at sea. The Franconia range was particularly clear, and Lafayette with Flume by its side stood out nobly, a large and a small pyramid against the blue. One of our number was sure that she saw the house on Moosilauke, and as she is a clergyman's daughter we could not gainsay her, especially as we ourselves had once seen it from Garvin Hill. The Sandwich range and Washington are not visible from Rattlesnake, being hidden by Bean Hill in Northfield, which one of our members says should be called Mean Hill.

The writer is often asked for a list of the mountains seen from Rattlesnake Hill. The prominent summits and a few of the near-by hills are here given 
in order, beginning with the Epsom hills east of Concord and looking north: Garvin Hill in Chichester; Catamount in Pittsfield; Peaked Hill in Gilmanton; Oak Hill (over Turtle Pond) in Loudon; the two Belknap mountains in Gilford; the scalloped crest of Ossipee (back of Lake Winnepesaukee); Bean Hill in Northfield; the eastern wall of the Franconia Notch, with some of the Waterville mountains, perhaps Osceola and Tecumseh; Flume; Lafayette; Cannon (where hangs the Profile) ; the Five-Step in Sanbornton; the three peaks of Moosilauke (the house is on the middle and highest one) ; the rounded outline of Carr in Warren back of Mount Stinson in Rumney; Plymouth Mountain near Bridgewater (a tiny miniature of Kearsarge); "the wave-like top" of Cardigan; Ragged in Andover; Kearsarge; Sunapee; the Mink Hills in Warner; Crany Hill in Henniker; Grand Monadnock; Crotched in Francestown; Pack Monadnock in Peterborough; the Uncanoonucs in Goffstown.

There are some gaps in this orbis terrarum, especially among the minor elevations, but it is believed that the list is approximately correct as far as it goes. The view from Rattlesnake is surprisingly extensive for a hill less than eight hundred feet high, but because there is no marked peak it is impossible to sweep 
the horizon from any one point. Thus while you are getting Ossipee and the Belknaps you are losing the Uncanoonucs.

We crossed the top of the hill, stirring up a flock of robins and two or three vesper sparrows. On reaching the signal station in the Farnum pasture (the highest part of the hill, 783 feet), marked by a triangle cut in the rock, we saw Turtle Pond in Pottertown, as blue as the bluebird's back, and we caught occasional gleams of the Merrimack. On top of the hill we added two varieties of rose haws to our collection, but we did not happen to see any of the scarlet fruit of the thorn bush, though it grows on this hill, nor any of the coral-red berries of the black alder.

We came down by the Farnum road, past the dark tarn which lies at the foot of an abandoned quarry. "The glad shout of color" from the autumn foliage called forth continuous shouts of appreciation from our party. The oaks in particular were magnificent masses of russet and bronze and metallic red. The writer has been surprised to see how many birds feed upon acorns. Last week in Rollins Park, while watching a flock of rusty blackbirds in the tree tops, we noticed a continuous shower falling upon and around us. Upon investigation we discovered that we were being 
pelted with the fragments of acorns which the birds were dropping from their beaks. A few days later, while boating on the Contoocook, we heard a hammering sound and discovered a blue jay pounding an acorn on a limb after the manner of the nuthatch.

We found a few edible though hardly ripe walnuts and chestnuts on Rattlesnake, but we were not looking at the hill from the small boy's point of view, and the sight of two hermit thrushes bathing in a pool as we came down the path gave us more pleasure than a whole bag of walnuts, chestnuts and butternuts combined.

Many people think that October is the loveliest month of the year. There can be no question about it this season.

October 17, 1905. 


\section{LIST OF FLOWERS ABOUT CONCORD.}

The following list contains the names of 540 species of flowering plants, belonging to 83 families, found in Concord and its immediate vicinity. The list has been compiled from "The Spring Flora of the Neighborhood of St. Paul's School" (by courtesy of the Rt. Rev. E. M. Parker, D. D.) ; from the records of the Wild Flower Club of Concord (founded in 1896) ; and from the writer's own observations. Bishop Parker's list numbers 286, all blossoming before July. The writer has catalogued 390 different species within the township of Concord. The classification employed is that of Gray's Manual, edition of 1889. In a few cases the nomenclature of Britton and Brown's Flora has been used for the newer and rarer species.

RANUNCULACEA.

Anenome cylindrica,

Long-Fruited Anenome.

A. Virginiana,

Thimble-Weed.

A. nemorosa,

Wind-Flower.

Hepatica triloba,

Liver-Leaf.

Thalictrum polygamum,

Tall Meadow-Rue.
Ranunculus multifidus,

Yellow Water-Crowfoot.

R. Flammula,

Spearwort.

R. reptans,

Creeping Crowfoot.

R. abortivus,

Small-Flowered Crowfoot.

R. acris,

Tall Buttercup.

R. bulbosus,

Bulbous Buttercup. 
R. sceleratus,

Cursed Crowfoot.

R. septentrionalis,

Early Crowfoot.

R. Pennsylvanicus,

Bristly Crowfoot.

R. repens.

Clematis Virginiana,

Virgin's Bower.

Caltha palustris,

Marsh Marigold.

Coptis trifolia,

Gold-Thread.

Aquilegia Canadensis,

Columbine.

Actaea alba,

White Baneberry.

A. rubra,

Red Baneberry.

BERBERIDACE .

Berberis vulgaris,

Barberry.

NYMPHÆACE $\mathrm{E}$.

Brasenia peltata,

Water-Shield.

Nymphaea odorata,

Water-Lily.

Nuphar advena,

Cow-Lily.

SARRACENIACEAE.

Sarracenia purpurea,

Pitcher-Plant.

PAPAVERACE正.

Sanguinaria Canadensis.

Bloodroot.
Chelidonium majus,

Celandine.

FUMARIACEAE.

Corydalis glauca, Pale Corydalis. Adlumia cirrhosa,

Climbing Fumitory.

CRUCIFERAE.

Nasturtium Armoracia, Horseradish.

Brassica Campestris, Turnip.

B. nigra,

Black. Mustard.

Capsella Bursa-pastoris, Shepherd's Purse.

Sisymbrium officinale,

Hedge Mustard.

Dentaria diphylla,

Pepper-root.

Barbarea vulgaris,

Winter Cress.

Raphanus Raphanistrum,

Wild Radish.

Cardamine hirsuta,

Small Bitter Cress.

Camelina sativa,

False Flax.

Lepidium Virginicum,

Peppergrass.

RESEDACEAE.

Reseda lutea,

Cut-leaved Mignonette. 


\section{CISTACEX.}

Helianthemum Canadense, Rock-Rose.

Hudsonia ericoides,

Lechea minor,

Pinweed.

L. maritima.

\section{VIOLACE 2.}

Viola palmata,

Common Blue Violet.

V. cucullata.

V. sagittata,

Arrow-leaved Violet.

D. blanda,

Sweet White Violet.

D. lanceolata,

Lance-leaved Violet.

D. rotundifolia,

Round-leaved Violet.

D. pubescens,

Downy Yellow Violet.

V. canina,

Dog Violet.

D. palustriformis.

V. primulaefolia,

Primrose-leaved Violet.

CARYOPHYLLACEA.

Lychnis Githago,

Corn Cockle.

Saponaria officinalis,

Bouncing Bet.

Silene Cucubalus,

Bladder Campion.

S. noctiflora,

Night-flowering Campion. H. corymbosum.
S. antirrhina,

Sleepy Catchfly.

S. dichotoma,

Forked Catchfly.

Stellaria media,

Chickweed.

S. longifolia,

Long-leaved Stitchwort.

S. borealis,

Northern Stitchwort.

Cerastium viscosum,

Mouse-ear Chickweed.

C. arvense,

Field Chickweed.

Sagina procumbens,

Pearlwort.

spergula arvensis,

Corn Spurrey.

Buda rubra,

Sand Spurrey:

Arenaria serpyllifolia,

Thyme-leaved Sandwort.

Moehringia laterifolia,

Blunt-leaved Sandwort.

PORTULACACEAE.

Portulaca oleracea,

Purslane.

HYPERICACEAE.

Hypericum perforatum,

St. Johnswort.

H. ellipticum.

H. maculatum.

H. Canadense.

H. mutilum. 
H. nudicaule,

Orange-grass.

Elodea campanulata,

Marsh St. Johnswort.

MALVACEA.

Malva rotundifolia,

Common Mallow.

Malva sylvestris,

High Mallow.

Abutilon Avicennae,

Velvet-leaf.

TILIACEÆ.

Tilia Americana,

Basswood.

GERANIACE $\approx$.

Oxalis Acetosella,

Wood-Sorrel.

o. corniculata,

Yellow Wood-Sorrel.

o. stricta.

Impatiens fulva,

Jewel-Weed.

I. pallida,

Pale Jewel-Weed.

Geranium Carolinianum.

Carolina Cranesbill.

Erodium cicutarium,

Hemlock Stork's-bill.

ILICINE $Æ$.

Ilex verticillata,

Black Alder.

I. laevigata,

Smooth Winterberry.
Nemopanthes fascicularis, Mountain Holly.

CELASTRACEÆ.

Celastrus scandens,

Bitter-sweet.

RHAMNACE $\circledast$.

Rhamnus alnifolia,

Alder-leaved Buckthorn.

Ceanothus Americanus,

New-Jersey-Tea.

VITACE $₫$.

Vitis Labrusca,

Northern Fox Grape.

V. riparia,

Wild Grape.

Ampelopsis quinquefolia,

Woodbine.

SAPINDACEAE.

Acer Pennsylvanicum,

Striped Maple.

A. spicatum,

Mountain Maple.

A. saccharinum,

Sugar Maple.

A. rubrum,

Red Maple.

A. dasycarpum,

White Maple.

ANACARDIACEA.

Rhus typhina,

Staghorn Sumach.

R. glabra,

Smooth Sumach. 
R. copallina,

Dwarf Sumach.

R. venenata,

Poison Sumach.

R. Toxicodendron,

Poison-Ivy.

POLYGALACEA.

Polygala paucifolia,

Fringed polygala.

$P$. polygama.

$P$. sanguinea,

Common Milkwort.

\section{LEGUMINOS $\nexists$.}

Lupinus perennis,

Wild Lupine.

Trifolium arvense,

Rabbit-foot Clover.

T. pratense,

Red Clover.

T. repens,

White Clover.

T. agrarium,

Yellow Clover.

T. procumbens,

Low Hop Clover.

T. hybridum,

Alsike Clover.

Baptisia tinctoria,

Wild Indigo.

Medicago denticulata,

Toothed Medic.

Cassia Marylandica,

Wild Senna.

Lespedeza capitata,

Bush Clover.
L. polystachya.

L. reticulata.

L. violacea.

Robinia Pseudacacia,

Locust.

Vicia Cracca, Vetch.

V. sativa,

Tare.

Desmodium nudiflorum,

Tick-Trefoil.

D. paniculatum.

D. Canadense.

D. rotundifolium.

D. Dillenii.

Amphicarpaea monoica, Hog-Peanut. Apios tuberosa,

Wild Bean.

Coronilla varia,

Purple Coronilla.

Melilotus alba,

White Melilot.

ROSACEIE.

Prunus Pennsylvanica,

Wild Red Cherry.

$P$. Virginiana,

Choke-Cherry.

$P$. serotina,

Wild Black Cherry.

Spiraea salicifolia,

Meadow-Sweet.

s. tomentosa,

Steeple-Bush.

Rubus odoratus,

Purple-Flowering Raspberry. 
R. triflorus,

Dwarf Raspberry.

R. strigosus,

Wild Raspberry.

R. occidentalis,

Black Raspberry.

R. villosus,

High Blackberry.

R. Canadensis,

Low Blackberry.

R. hispialus,

Swamp Blackberry.

Dalibarda repens.

Physocarpus opulifolius,

Nine-Bark.

Geum album,

White Avens.

G. strictum,

Yellow Avens.

G. Dirginianum.

G. rivale,

Water Avens.

Fragaria Virginiana,

Field Strawberry.

F. vesca,

Wood Strawberry.

Potentilla Norvegica,

Hairy Cinquefoil.

$P$. Canadensis,

Common Cinquefoil.

$P$. argentea,

Silvery Cinquefoil.

Agrimonia Eupatoria,

Agrimony.

Rosa lucida,

Rose.

R. rubiginosa,

Sweetbrier.
Pyrus arbutifolia,

Choke-berry.

P. melanocarpa,

Dogberry.

P. Americana,

Mountain-Ash.

P. sambucifolia,

Mountain-Ash.

Crataegus coccinea,

Hawthorn.

C. tomentosa.

C. mollis.

Amelanchier Canadensis,

Shad-bush.

A. oblongifolia.

SAXIFRAGACE $\nexists$.

Saxifraga Virginiensis, Rock Saxifrage.

S. Pennsylvanica,

Swamp Saxifrage.

Tiarella cordifolia,

False Mitrewort.

Chrysoplenium Americanum,

Golden Saxifrage.

Ribes Cynosbati,

Gooseberry.

R. prostatum,

Fetid Currant.

R. floridum,

Wild Black Currant.

CRASSULACEA.

Sedum Telephium,

Live-For-Ever.

S. acre,

Iceland Moss. 
Penthorum sedoides,

Ditch-Stone-Crop.

DROSERACEA.

Drosera rotundifolia,

Round-leaved Sundew.

D. intermedia.

HAMAMELIDE $\approx$.

Hamamelis Virginiana,

Witch-Hazel.

HALORAGEA.

Callitriche verna,

Water Starwort.

MELASTOMACE $\approx$.

Rhexia Virginica,

Meadow-Beauty.

LYTHRACEA.

Lythrum Salicaria,

Purple Loosestrife.

L. alatum,

Wing-angled Loosestrife. Decodon verticillatus,

Swamp Loosestrife.

ONAGRACE $\circledast$.

Enothera pumila,

Small Evening Primrose. Heracleum lanatum,

Enothera biennis,

Common Evening Primrose.

CE. fruticosa,

Sundrops.

CE. chrysantha.

EE. cruciata.
Epilobium coloratum,

Small Willow-Herb.

E. angustifolium,

Fireweed.

Circaea Lutetiana,

Enchanter's Nightshade.

CUCURBITACE $A$.

Echinocystis lobata,

Wild Balsam-Apple.

Sicyos angulatus,

Bur-Cucumber.

UMBELLIFER $Æ$.

Daucus Carota, Wild Carrot.

Thaspium aureum, Meadow Parsnip.

Sanicula Marylandica, Black Snakeroot.

S. Canadensis.

Cicuta maculata,

Water Hemlock.

Cicuta bulbifera.

sium cicutaefolium,

Water Parsnip.

Pastinaca sativa, Common Parsnip.

Zizia aurea,

Early Meadow Parsnip.

Cow Parsnip.

Cryptotaenia Canadensis,

Honewort.

Carum Carui,

Caraway.

Hydrocotyle Americana,

Water Pennywort. 
ARALIACE $A$.

Aralia racemosa,

Spikenard.

A. nudicaulis,

Wild Sarsaparilla.

A. trifolia,

Dwarf Ginseng.

CORNACEAE.

Cornus Canadensis,

Bunch-berry.

C. circinata,

Round-leaved Dogwood.

C. stolonifera,

Red-osier Dogwood.

C. alternifolia,

Alternate-leaved Dogwood.

C. paniculata,

Panicled Dogwood.

C. sericea,

Kinnikinnik.

Nyssa sylvatica,

Pepperidge.

CAPRIFOLIACEA.

Sambucus Canadensis,

Elder, Common.

s. racemosa,

Red-berried Elder.

Viburnum lantanoides,

Hobble-bush.

V. Opulus,

Cranberry-tree.

V. acerifolium,

Maple-leaved Viburnum.

V. dentatum,

Arrow-wood.
V. cassinoides,

Withe-rod.

V. nudum.

V. Lentago,

Sheep-berry.

Linnaea borealis,

Twin-flower.

Lonicera ciliata,

Fly Honeysuckle.

Diervilla trifida,

Bush Honeysuckle.

RUBIACEAE.

Houstonia caerulea, Bluets.

H. longifolia,

Mitchella repens,

Partridge-berry.

Cephalanthus occidentalis, Button-bush.

Galium trifidum,

Bedstraw, Common.

G. triflorum,

Sweet-scented Bedstraw.

G. asprellum,

Rough Bedstraw.

COMPOSITA.

Erigeron Canadensis,

Horse-weed.

E. annuus,

Daisy Fleabane.

E. bellifodius,

Robin's Plantain.

E. Philadelphicus,

Common Fleabane. Antennaria plantaginifolia,

Early Everlasting. 
Rudbeckia hirta,

Cone-flower.

Anthemis Cotula,

May-weed.

Achillea Millefolium,

Yarrow.

Chrysanthemum Leucanthemum,

White Daisy.

Senecio aureus,

Golden Ragwort.

Krigia Virginica,

Dwarf Dandelion.

Cirsium arvense,

Canada Thistle.

Cirsium lanceolatum,

Common Thistle.

Leontodon autumnalis,

Fall Dandelion.

Taraxacum officinale,

Dandelion.

Taraxacum erythrospermum,

Red-seeded Dandelion.

Mikania scandens,

Climbing Hemp-Weed. Anaphilis margaritacea,

Pearly Everlasting.

Gnaphalium polycephalum,

Fragrant Life Everlasting.

Hieracium Canadense,

Canada Hawkweed.

H. venosum,

Rattlesnake-Weed.

H. aurantiacum,

Devil's Paint-brush.

H. scabrum,

Rough Hawkweed.
H. paniculatum,

Panicled Hawkweed.

Inula Helenium,

Elecampane.

Helianthus tuberosus,

Jerusalem Artichoke.

H. giganteus,

Wild Sunflower.

Bidens frondosa,

Sticktight.

$B$. chrysanthemoides,

Larger Bur-Marigold.

B. cernua,

Smaller Bur-Marigold.

Lactuca Canadensis,

Wild Lettuce.

Sonchus oleraceus,

Sow Thistle.

Eupatorium purpureum,

Joe-Pye-Weed.

E. perfoliatum,

Thoroughwort.

E. ageratoides,

White Snakeroot.

Cichorium Intybus,

Chicory.

Tanacetum vulgare,

Tansy.

Prenanthes serpentaria,

Lion's-Foot.

Ambrosia artemisiaefolia, Roman Wormwood.

Petasites palmata,

Sweet Coltsfoot.

WHITE ASTERS:

Aster ericoides.

A. umbellatus. 
A. multiflorus.

A. acuminatus.

Sericocarpus solidagineus,

White-topped Aster.

BLUE ASTERS:

Aster sagittifolius.

A. patens.

A. puniceus.

A. cordifolius.

A. undulatus.

A. laevis.

Solidago Canadensis, Goldenrod.

S. lanceolata.

S. nemoralis.

S. rigida.

S. odorata.

S. latifolia.

S. stricta.

S. arguta.

S. altissima.

S. serotina.

S. puberula.

S. patula.

S. rugosa.

S. juncea.

S. caesia,

Blue-stemmed Goldenrod.

S. bicolor,

Silver-rod.

LOBELIACE\#.

Lobelia cardinalis,

Cardinal-Flower.

L. inflata,

Indian Tobacco.

L. spicata,

Spiked Lobelia.
L. Dortmanna,

Water Lobelia.

CAMPANULACEA.

Campanula aparinoides,

Bellflower.

ERICACE\#.

Gaylussacia resinosa,

Huckleberry.

Vaccinium Pennsylvanicum,

Dwarf Blueberry.

V. vacillans,

Low Blueberry.

V. corymbosum,

Swamp Blueberry.

V. Oxycoccus,

Small Cranberry.

V. macrocarpon,

Large Cranberry.

Chiogenes serpyllifolia, Creeping Snowberry.

Epigaea repens,

Mayflower.

Andromeda ligustrina,

Privet Andromeda.

A. polifolia.

Cassandra calyculata,

Leather-Leaf.

Gaultheria procumbens,

Checkerberry.

Kalmia latifolia,

Laurel, Mountain.

$K$. angustifolia,

Sheep Laurel.

K. glauca,

Pale Laurel.

Rhododendron nudiflorum,

Azalea. 
Rhododendron Rhodora,

Leafless Rhodora.

Chimaphila umbellata,

Pipsissewa.

Moneses grandiflora,

One-flowereả Pyrola.

Pyrola rotundifolia,

Shin-leaf.

$P$. secunda.

$P$. elliptica.

$P$. chlorantha.

Monotropa uniflora,

Indian Pipe.

M. Hypopitys,

Pine-Sap.

PRIMULACEA.

Trientalis Americana,

Starflower.

Lysimachia quadrifolia,

Four-leaved Loosestrife.

L. stricta.

Steironema ciliatum,

Fringed Loosestrife.

$$
\text { OLEACEX. }
$$

Fraxinus Americana,

White Ash.

F. sambucifolia,

Black Ash.

F. pubescens,

Red Ash.

APOCYNACEE.
ASCLEPIADACEAE.

Asclepias Cornuti,

Common Milkweed.

A. incarnata,

Swamp Milkweed.

A. purpurascens,

Purple Milkweed.

A. phytolaccoides,

Poke Milkweed.

A. pulchra.

A. obtusifolia.

A. tuberosa,

Butterfly-Weed.

GENTIANACE $\nexists$.

Menyanthes trifoliata, Buck-bean.

Limnanthemum lacunosum,

Floating-Heart.

Gentiana crinita,

Fringed Gentian.

G. linearis,

Soapwort Gentian.

G. Andrewsii,

Closed Gentian.

POLEMONIACE $A$.

Phlox subulata,

Moss Pink.

BORRAGINACEE.

Apocynum androsaemifolium, Symphytum officinale,

Dogbane.

A. cannabinum,

Indian Hemp.
Comfrey.

Echium vulgare,

Viper's Bugloss. 
CONVOLVULACEAE.

Convolvulus spithamaeus,

Common Bindweed.

C. arvensis,

European Bindweed.

C. sepium,

Hedge Bindweed.

Cuscuta Gronovii,

Common Dodder.

SOLANACEF.

Physalis Virginiana,

Ground Cherry.

Datura Tatula,

Thorn Apple.

Solanum Dulcamara,

Nightshade.

SCROPHULARIACE $\$$.

Verbascum Thapsus,

Mullein.

V. Blattaria,

Moth Mullein.

Chelone glabra,

Turtle-Head.

Gratiola aurea,

Hedge Hyssop.

Gerardia quercifolia,

Smooth False Foxglove.

G. pedicularis,

Fern-leaved False Foxglove.

G. tenuifolia,

Slender Gerardia.

Linaria vulgaris,

Butter and Eggs.
L. Canadensis,

Blue Toadflax.

Veronica scutellata,

Speedwell.

V. serpyllifolia,

Thyme-leaved Speedwell.

Pedicularis Canadensis,

Wood Betony.

Melampyrum Americanum,

Cow-wheat.

Scrophularia nodosa,

Figwort.

Pentstemon laevigatus,

Smooth Beard-Tongue.

Mimulus ringens,

Monkey-Flower.

OROBANCHACEA.

Aphyllon uniflorum,

One-flowered Cancer-root.

LENTIBULARIACEæ.

Utricularia vulgaris,

Common Bladderwort.

VERBENACEA.

Verbena urticaefolia,

White Vervain.

V. hastata,

Blue Vervain.

LABIAT $A$.

Mentha Canadensis,

Wild Mint.

M. viridis,

Spearmint. 
M. piperita,

Peppermint.

Nepeta Cataria,

Catnip.

N. Glechoma,

Ground Ivy.

Scutellaria laterifolia,

Mad-dog Skull-cap.

S. galericulata,

Skull-cap.

Brunella vulgaris,

Heal-all.

Trichostema dichotomum, Blue-Curls.

Galeopsis Tetrahit,

Hemp Nettle.

Physostegia Virginiana,

False Dragon-Head.

Monarda didyma,

Oswego Tea.

Pycnanthemum lanceolatum, Mountain Mint.

Leonurus cardiaca,

Common Motherwort.

Hedeoma pulegioides, American Pennyroyal.

Monarda didyma,

Oswego Tea.

M. fistulosa,

Wild Bergamot.

Lycopus sinuatus,

Water Horehound.

L. Virginicus,

Bugle-Weed.

PLANTAGINACEAE.

Plantago major, Plantain.
P. lanceolata, Rib-grass.

AMARANTACE $\nexists$.

Amarantus retroflexus, Pig-weed.

CHENOPODIACE $A$.

Chenopodium album, Goosefoot.

C. Botrys, Jerusalem-Oak.

PHYTOLACCACEÆ.

Phytolacca decandra, Pokeweed.

POLYGONACEÆ.

Rumex crispus,

Curled Dock.

R. obtusifolius,

Bitter Dock.

R. Acetosella,

Sorrel.

Polygonum aviculare,

Knot-grass.

P. Persicaria,

Lady's Thumb.

P. sagittatum,

Tear-Thumb.

P. arifolium,

Halberd-leaved Tear-

Thumb.

P. amphibium,

Amphibious Knotweed.

P. articulatum,

Sand Knotweed.

P. Pennsylvanicum,

Pink Knotweed. 
$P$. hydropiperoides,

Mild Water Pepper.

P. dumetorum,

Hedge Buckwheat.

P. scandens,

Climbing False Buckwheat.

ARISTOLOCHIACE $\mathrm{E}$. Asarum Canadense,

Wild Ginger.

LAURACEA.

Sassafras officinale,

Sassafras.

Lindera Benzoin,

Spice-bush.

THYMELEACE玉.

Dirca palustris,

Leather-wood.

SANTALACEE.

Comandra umbellata,

Bastard Toad-flax.

EUPHORBIACE丹.

Euphorbia Cyparissias,

Cypress Spurge.

E. maculata,

Spurge.

URTICACEA.

Ulmus Americana,

Elm.

PLATANACE $刃$.

Platanus occidentalis, Button-wood.
JUGLANDACEÆ.

Juglans cinerea,

Butter-nut.

Carya alba,

Shag-bark Hickory.

C. porcina,

Pig-nut.

MYRICACE

Myrica Gale,

Sweet Gale.

M. asplenifolia,

Sweet Fern.

$M$. cerifera,

Bayberry.

CUPULIFER $\approx$.

Betula lenta,

Black Birch.

B. lutea,

Yellow Birch.

B. populifolia,

Gray Birch.

B. papyrifera,

Paper Birch.

Alnus incana,

Alder.

Corylus Americana,

Hazel-nut.

Ostrya Virginica,

Hop Hornbeam.

Carpinus Caroliniana,

Hornbeam.

Quercus alba,

White Oak.

Q. rubra,

Red Oak. 
Q. coccinea,

Scarlet Oak.

Q. tinctoria,

Yellow-barked Oak.

Q. ilicifolia,

Scrub Oak.

Q. prinoides,

Scrub Chestnut Oak.

Castanea sativa,

Chestnut.

C. Americana.

Fagus ferruginea,

American Beech.

SALICACEA.

Salix alba,

White Willow.

S. discolor,

Glaucous Willow.

S. humilis,

Prairie Willow.

S. cordata,

Heart-leaved Willow.

Populus tremuloides,

American Aspen.

$P$. grandidentata,

Large-toothed Aspen.

$P$. balsamifera,

Balm of Gilead.

$P$. dilatata.

P. alba,

White Poplar.

CONIFER $\AA$.

Pinus strobus,

White Pine.

$P$. rigida,

Pitch Pine.
P. resinosa,

Red Pine.

Picea nigra,

Black Spruce.

Tsuga Canadensis, Hemlock.

Abies balsamea,

Balsam.

Larix Americana,

Larch.

Juniperus Virginiana, Red Cedar.

J. communis,

Juniper.

Taxus Canadensis, Ground Hemlock.

ORCHIDACEAE.

Corallorhiza innata, Small Coral-root.

C. multiflora,

Large Coral-root.

Pogonia ophioglossoides,

Adder's-Mouth.

$P$. affinis.

Habenaria bracteata,

Rein Orchis.

H. dilatata,

Northern White Orchis.

H. Hookeri.

$H$. virescens,

Green Orchis.

H. lacera,

Ragged Fringed Orchis.

H. blephariglottis,

White Fringed Orchis. 
H. orbiculata,

Large Round-leaved Orchis.

H. tridentata,

Small Green Orchis.

H. fimbriata,

Large Purple Fringed Orchis.

H. psycodes,

Small Purple Fringed

Orchis.

Cypripedium acaule,

Stemless Lady's Slipper.

Cypripedium pubescens,

Yellow Lady's Slipper.

C. spectabile,

Showy Lady's Slipper.

Calopogon pulchellus,

Calopogon.

Arethusa bulbosa,

Arethusa.

Goodyera pubescens,

Rattlesnake-Plantain.

G. repens,

Lesser RattlesnakePlantain.

Liparis Loeselii,

Fen Orchis.

Spiranthes cernua,

Ladies' Tresses.

S. gracilis,

Slender Ladies' Tresses.

S. praecox.

IRIDACEA.

Iris versicolor,

Flower-de-Luce.
Sisyrinchium angustifolium,

Blue-eyed Grass.

S. anceps.

LILIACE $\circledast$.

Smilax herbacea,

Carrion-Flower.

S. rotundifolia,

Horse-brier.

Polygonatum biflorum,

Solomon's Seal.

Smilacina racemosa,

False Spikenard.

S. stellata,

Star-leaved Solomon's Seal.

S. trifolia,

Three-leaved Solomon's

Seal.

Streptopus roseus,

Twisted-stalk.

clintonia borealis,

Northern Clintonia.

Uvularia perfoliata,

Bellwort.

U. sessilifolia,

Bellwort.

Maianthemum Canadense.

Erythronium Americanum.

Adder's-tongue.

Lilium Philadelphicum, Red Lily.

L. Canadense,

Yellow Lily.

Medeola Virginiana, Indian-Cucumber.

Trillium erectum,

Wake Robin. 
T. cernuum,

Nodding Trillium.

T. erythrocarpum,

Painted Trillium.

Veratrum viride,

Indian-Poke.

PONTEDERIACEE.

Pontederia cordata,

Pickerel-weed.

TYPHACE $\mathrm{E}$.

Sparganium simplex,

Bur-reed.

Typha latifolia,

Cat-tail.

ARACEÆ.

Arisaema triphyllum, Jack-in-the-Pulpit.
Calla palustris, Wild Calla.

symplocarpus foetidus, Skunk-Cabbage.

Acorus Calamus,

Sweet-Flag.

ALISMACE $\nexists$.

Alisma Plantago-aquatica, Water-Plantain.

Sagittaria latifolia, Broad-leaved Arrowhead.

NAIADACEA.

Potamogeton heterophyllus, Pondweed.

ERIOCAULEA.

Eriocaulon septangulare, Pipewort. 



\section{ALPHABETICAL INDEX OF FLOWERS ABOU' CONCORD, 540.}

PAGE. Abies balsamea........ 117 Abutilon Avicennae..... 106 Acer dasycarpum....... 106 Acer Pennsylvanicum.... 106 Acer rubrum.......... 106 Acer saccharinum...... 106 Acer spicatum......... 106 Achillea Millefolium..... 111 Acorus Calamus........ 119 Actaea alba........... 104 Actaea rubra.......... 104 Adder's Mouth.......... 117 Adder's-tongue ........ 118 Adlumia cirrhosa....... 104 Agrimonia Eupatoria..... 108 Agrimony .......... 108 Alder .............. 116 Alder, Black.......... 106 Alisma Plantago-aquatica 119 ALISMACE $F$........ 119 Alnus incana......... 116 AMARANTACE $A$...... 115 Amarantus retroflexus.... 115 Ambrosia artemisiaefolia. 111 Amelanchier Canadensis. 108 Amelanchier oblongifolia. 108 Ampelopsis quinquefolia. 106
PAGE.

Amphicarpaea monoica... 107

ANACARDIACEA ..... 106

Anaphilis margaritacea.. 111

Andromeda ligustrina.... 112

Andromeda polifolia..... 112

Andromeda, Privet....... 112

Anemone cylindrica..... 103

Anemone nemorosa..... 103

Anemone Virginiana..... 103

Anemone, Long-fruited... 103

Antennaria plantaginifolia

Anthemis Cotula....... 111

Aphyllon uniflorum...... 114

Apios tuberosa......... 107

Apple, Thorn.......... 114

APOCYNACEA ....... 113

Apocynum androsaemifo-

$\operatorname{lium} \ldots \ldots \ldots \ldots \ldots 113$

Apocynum cannabinum... 113

Aquilegia Canadensis... 104

ARACE $\nexists \ldots \ldots \ldots \ldots .119$

ARALIACE $A$........ 110

Aralia nudicaulis....... 110

Aralia racemosa........ 110

Aralia trifolia.......... 110

Arenaria serpyllifolia.... 105 
Arethusa ........... 118

Arethusa bulbosa....... 118

Arisaema triphyllum..... 119

ARISTOLOCHIACEÆ ... 116

Arrowhead, Broad-leaved. 119

Arrow-wood ......... 110

Artichoke, Jerusalem.... 111

Asarum Canadense...... 115

ASCLEPIADACE $A$..... 113

Asclepias Cornuti....... 113

Asclepias incarnata..... 113

Asclepias obtusifolia..... 113

Asclepias phytolaccoides. 113

Asclepias pulchra....... 113

Asclepias purpurascens... 113

Asclepias tuberosa...... 113

Ash, Black.......... 113

Ash, Red........... 113

Ash, White.......... 113

Aspen, American....... 117

Aspen, Large-toothed..... 117

Aster acuminatus....... 112

Aster cordifolius........ 112

Aster ericoides......... 111

Aster laevis.......... 112

Aster multifloms....... 112

Aster patens........... 112

Aster puniceus......... 112

Aster sagittifolius....... 112

Aster umbellatus....... 111
Aster undulatus........ 112

Aster, White-topped..... 112

Avens, Water.......... 108

Avens, White.......... 108

Avens, Yellow......... 108

Azalea ............ 112

Balm of Gilead....... 117

Balsam ............. 117

Balsam-Apple, wild..... 109

Baneberry, Red......... 104

Baneberry, White....... 104

Baptisia tinctoria....... 107

Barbarea vulgaris...... 104

Barberry ............ 104

Bass-wood ........... 106

Bayberry ........... 116

Bean, wild........... 107

Beard-Tongue, Smooth... 114

Bedstraw, Common...... 110

Bedstraw, Rough....... 110

Bedstraw, Sweet-scented. 110

Beech, American....... 117

Bellflower .......... 112

Bellwort ............ 118

BERBERIDACE $A$..... 104

Berberis vulgaris....... 104

Bergamot, Wild........ 115

Betony, Wood......... 114 
Betula lenta.......... $116 \mid$ Brunella vulgaris....... 115

Betula lutea.......... 116 Buck-bean .......... 113

Betula papyrifera....... 116 Buckthorn, Alder-leaved. 106

Betula populifolia....... 116

Bidens cernua......... 111

Bidens chrysanthemoides 111

Bidens frondosa....... 111

Bindweed, Common...... 114

Bindweed, European. .... 114

Bindweed, Hedge....... 114

Birch, Black.......... 116

Birch, Gray.......... 116

Birch, Paper.......... 116

Birch, Yellow......... 116

Bitter-sweet ......... 106

Blackberry, High....... 108

Blackberry, Low........ 108

Blackberry, Swamp..... 108

Bladderwort, Common.... 114

Bloodroot .............. 104

Blueberry, Dwarf....... 112

Blueberry, Low........ 112

Blueberry, Swamp...... 112

Blue-Curls ........... 115

Bluets ............. 110

BORRAGINACE $A 2 \ldots . .113$

Bouncing Bet.......... 105

Brasenia peltata........ 104

Brassica Campestris.... 104

Brassica nigra......... 104

Buckwheat, Climbing

False ............ 116

Buckwheat, Hedge. ..... 116

Buda rubra............ 105

Bugle-Weed ........... 115

Bugloss, Viper's....... 113

Bunch-berry ......... 110

Bur-Cucumber ........ 109

Bur-Marigold, Larger.... 111

Bur-Marigold, Smaller... 111

Bur-reed ............ 119

Butter and Eggs....... 114

Buttercup, Bulbous...... 103

Buttercup, Tall........ 103

Butterfly-weed ........ 113

Butter-nut .......... 116

Button-bush .......... 110

Button-wood ......... 116

Calla palustris......... 119

Calla, Wild........... 119

Callitriche verna........ 109

Calopogon pulchellus..... 118

Calopogon ........... 118

Caltha palustris........ 104

Camelina sativa....... 104 
INDEX.

Campanula aparinoides... $112 \mid$ Cephalanthus occidentalis 110 CAMPANULACE $\mathbb{E}$..... 112 Campion, Bladder....... 105 Campion, Night-flowering 105 Cancer-root, One-flowered 114 CAPRIFOLIACEA ..... 110 Capsella Bursa-pastoris... 104 Caraway ............ 109 Cardamine hirsuta...... 104 Cardinal-Flower ....... 112 Carpinus Caroliniana.... 116 Carrion-Flower ....... 118 Carrot, Wild........... 109 Carum Carui........... 109 Carya alba............ 116 Carya porcina......... 116 CARYOPHYLLACE I. .. 105 Cassandra calyculata..... 112 Cassia Marylandica..... 107 Castanea Americana.... 117 Castanea sativa......... 117 Catchfly, Forked........ 105 Catchfly, Sleepy......... 105 Catnip ............. 115 Cat-tail .............. 119 Ceanothus Americanus... 106 Cedar, Red........... 117 Celandine ............. 104 CELASTRACE $\ldots$...... 106 Celastrus scandens...... 106 Cerastium arvense...... 105 Cerastium viscosum..... 105 Checkerberry ......... 112 Chelidonium majus...... 104 Chelone glabra......... 114 CHENOPODIACE Chenopodium album..... 115 Chenopodium Botrys..... 115 Cherry, Choke......... 107 Cherry, Wild Black..... 107 Cherry, Wild Red...... 107 Chestnut ........... 117 Chickweed, Common..... 105 Chickweed, Field....... 105 Chickweed, Mouse-ear.... 105 Chicory ............. 111 Chimaphila umbellata.... 112 Chiogenes serpyllifolia... 112 Choke-berry .......... 108 Chrysanthemum leucanthemum ........... 111 Chrysoplenium Americanum .............. 108 Cichorium Intybus....... 111 Cicuta bulbifera......... 109 Cicuta maculata........ 109 Cinquefoil, Common...... 108 Cinquefoil, Hairy....... 108 Cinquefoil, Silvery...... 108 
Circaea Lutetiana...... 109 Corn Cockle.......... 105

Cirsium arvense........ 111

Cirsium lanceolatum..... 111

CISTACEA .......... 105

Clematis Virginiana..... 104

Clintonia borealis....... 118

Clintonia, Northern..... 118

Clover, Alsike........ 107

Clover, Bush.......... 107

Clover, Low Hop....... 107

Clover, Rabbit-foot...... 107

Clover, Red........... 107

Clover, White......... 107

Clover, Yellow......... 107

Coltsfoot ........... 111

Columbine ........... 104

Comandra umbellata..... 116

Comfrey ............ 113

COMPOSIT 2 ......... 110

Cone-flower ........... 111

CONIFERA .......... 117

CONVOLVULACEAE .... 114

Convolvulus arvensis..... 114

Convolvulus sepium ..... 114

Convolvulus spithamaeus 114

Coptis trifolia......... 104

Corallorhiza innata..... 117

Corallorhiza multiflora... 117

Coral-root, Large........ 117

Coral-root, Small....... 117

CORNACE $A$.......... 110

Cornus alternifolia...... 110

Cornus Canadensis...... 110

Cornus circinata ....... 110

Cornus paniculata....... 110

Cornus sericea.......... 110

Cornus stolonifera...... 110

Coronilla, Purple....... 107

Coronilla varia......... 107

Corydalis glauca........ 104

Corydalis, Pale......... 104

Corylus Americana...... 116

Cow-Lily ........... 104

Cow-wheat ........... 114

Cranberry, Large....... 112

Cranberry, Small....... 112

Cranberry-tree ........ 110

Cranesbill, Carolina..... 106

CRASSULACE $A \pm \ldots \ldots .108$

Crataegus coccinea...... 108

Crataegus mollis........ 108

Crataegus tomentosa..... 108

Cress, Small Bitter..... 104

Cress, Winter.......... 104

Crowfoot, Bristly....... 104

Crowfoot, Creeping...... 103

Crowfoot, Cursed........ 104

Crowfoot, Early........ 104

Crowfoot, Small-flowered. 103 
INDEX.

CRUCIFER E ......... 104

Cryptotenia Canadensis.. 109 CUCURBITACE $\nexists \ldots . .109$

Currant, Fetid......... 108

Currant, Wild Black..... 108

CUPULIFER $\mathbb{E}$....... 116

Cuscuta Gronovii....... 114

Cypripedium acaule..... 118

Cypripedium pubescens... 118

Cypripedium spectabile... 118

Daisy, White......... 111

Dalibarda repens....... 108

Dandelion, Common..... 111

Dandelion, Dwarf....... 111

Dandelion, Fall........ 111

Dandelion, Red-seeded... 111

Datura Tatula......... 114

Daucus Carota.......... 109

Decodon verticillatus.... 109

Dentaria diphylla....... 104

Desmodium Canadense... 107

Desmodium Dillenii..... 107

Desmodium nudiflorum... 107

Desmodium paniculatum. 107

Desmodium rotundifolium 107

Devil's Paint-brush...... 111

Diervilla trifida........ 110

Dirca palustris......... 115
Ditch-Stone-Crop ..... 109

Dock, Bitter ......... 115

Dock, Curled.......... 115

Dodder, Common........ 114

Dogbane ............. 113

Dogberry ............ 108

Dogwood, Alternate-leaved 110

Dogwood, Panicled...... 110

Dogwood, Red-osier..... 110

Dogwood, Round-leaved.. 110

Dragon-Head, False..... 115

Drosera intermedia...... 109

Drosera rotundifolia.... 109

DROSERACE $A$....... 109

Echinocystis lobata..... 109

Echium vulgare......... 113

Elder, Common........ 110

Elder, Red-berried...... 110

Elecampane .......... 111

Elm .............. 116

Elodea campanulata..... 106

Epigaea repens......... 112

Epilobium angustifolium. 109

Epilobium coloratum..... 109

ERICACE $A$......... 112

Erigeron annuus........ 110

Erigeron bellidifolius.... 110

Erigeron Canadensis..... 110 
Erigeron Philadelphicus. $110 \mid$ Fragaria vesca.......... 108 ERIOCAULEA ........ 119 Eriocaulon septangulare. 119 Erodium cicutarium..... 106 Erythronium Americanum 118 Eupatorium ageratoides.. 111 Eupatorium perfoliatum. 111 Eupatorium purpureum.. 111 Euphorbia Cyparissias... 116 Euphorbia maculata.... 116 EUPHORBIACEA ..... 116 Everlasting, Early...... 110 Everlasting, Fragrant

Life ........... 111

Everlasting, Pearly..... 111

Fagus ferruginea....... 117

Fern, Sweet......... 116

Figwort .......... 114

Fireweed ........... 109

Flax, False........... 104

Fleabane, Common...... 110

Fleabane, Daisy........ 110

Floating-Heart ....... 113

Flower-de-Luce ........ 118

Foxglove, Fern-leaved

False ........... 114 Foxglove, Smooth False.. 114 Fragaria Virginiana..... 108 Fraxinus Americana.... 113 Fraxinus pubescens...... 113 Fraxinus sambucifolia... 113 FUMARIACE $A$....... 104 Fumitory, Climbing..... 104

Gale, Sweet.......... 116

Galeopsis Tetrahit...... 115

Galium asprellum....... 110

Galium trifidum....... 110

Galium triflorum ....... 110

Gaylussacia resinosa.... 112

Gaultheria procumbens... 112

Geum album........... 108

Geum rivale........... 108

Geum strictum......... 108

Geum Virginianum...... 108

Gentian, Closed........ 113

Gentian, Fringed...... 113

Gentian, Soapwort...... 113

Gentiana Andrewsii..... 113

Gentiana crinita....... 113

Gentiana linearis....... 113

GENTIANACE $\nexists \ldots \ldots \ldots 113$

GERANIACE $A$....... 106

Geranium Carolinianum.. 106

Gerardia pedicularis..... 114

Gerardia quercifolia..... 114 
Gerardia tenuifolia..... $114 \mid$ Habenaria virescens.... 117

Gerardia, Slender....... 114 Ginger, Wild......... 116

Ginseng, Dwarf........ 110

Gnaphalium polycephalum 111

Gold-Thread .......... 104

Goldenrod ............ 112

Goldenrod, Blue-stemmed. 112

Goodyera pubescens..... 118

Goodyera repens........ 118

Gooseberry .......... 108

Goosefoot ........... 115

Grape, Northern Fox.... 106

Grape, Wild.......... 106

Grass, Blue-eyed....... 118

Gratiola aurea.......... 114

Ground-Cherry ......... 114

Ground-Ivy .......... 115

Ground-nut ......... 110

Habenaria blephariglottis 117

Habenaria bracteata..... 117

Habenaria dilatata...... 117

Habenaria fimbriata..... 118

Habenaria Hookeri...... 117

Habenaria lacera........ 117

Habenaria orbiculata.... 118

Habenaria psycodes..... 118

Habenaria tridentata.... 118

HALORAGE $\mathrm{E}$........ 109

HAMAMELIDE $\AA$...... 109

Hamamelis Virginiana... 109

Hawkweed, Canada...... 111

Hawkweed, Panicled..... 111

Hawkweed, Rough...... 111

Hawthorn ......... 108

Hazel-nut .......... 116

Heal-all ............ 115

Hedeoma pulegioides..... 114

Helianthemum Canadense 105

Helianthus giganteus.... 111

Helianthus tuberosus.... 111

Hemlock ............ 117

Hemlock, Ground....... 117

Hemlock, Water........ 109

Hemp, Indian........ 113

Hemp-weed, Climbing.... 111

Hepatica triloba........ 103

Heracleum lanatum..... 109

Hickory, Shag-bark..... 116

Hieracium aurantiacum.. 111

Hieracium Canadense.... 111

Hieracium paniculatum.. 111

Hieracium scabrum..... 111

Hieracium venosum..... 111

Hobble-bush ......... 110

Hog-Peanut ......... 107

Holly, Mountain....... 106 
Honewort .......... 109

Honeysuckle, Bush...... 110

Honeysuckle, Fly....... 110

Hop Hornbeam........ 116

Hornbeam ........... 116

Horehound, Water...... 115

Horse-brier ......... 118

Horseradish .......... 104

Horse-weed .......... 110

Houstonia caerulea..... 110

Houstonia longifolia..... 110

Huckleberry ......... 112

Hudsonia ericoides...... 105

Hydrocotyle Americana. . 109

HYPERICACEAE ...... 105

Hypericum Canadense... 105

Hypericum corymbosum.. 105

Hypericum ellipticum.... 105

Hypericum maculatum... 105

Hypericum mutilum.... 105

Hypericum nudicaule.... 106

Hypericum perforatum. . . 105

Hyssop, Hedge......... 114

Iceland-Moss .......... 108

Ilex laevigata......... 106

Ilex verticillata........ 106

ILICINEA .......... 106

Impatiens fulva........ 106
Impatiens pallida...... 106

Indian-Cucumber ...... 118

Indian-Pipe $\ldots \ldots \ldots \ldots \ldots 113$

Indian-Poke $\ldots \ldots \ldots \ldots 119$

Indigo, Wild.......... 107

Inula Helenium......... 111

IRIDACE $A$. ......... 118

Iris versicolor......... 118

Ivy, Ground.......... 115

Ivy, Poison.......... 107

Jack-in-the-Pulpit . . . . 119

Jerusalem-Oak ........ 115

Jewel-Weed .......... 106

Jewel-Weed, Pale....... 106

Joe-Pye-Weed ......... 111

JUGLANDACE

Juglans cinerea....... 116

Juniper ............. 117

Juniperus communis.... 117

Juniperus Virginiana.... 117

Kalmia angustifolia..... 112

Kalmia glauca......... 112

Kalmia latifolia........ 112

Kinnikinnik ......... 110

Knot-grass .......... 115

Knotweed, Amphibious... 115 
Knotweed, Pink........ $115 \mid$ Lespedeza reticulata.... 107

Knotweed, Sand....... 115

Krigia Virginica....... 111

Lespedeza violacea...... 107

Lettuce, Wild.......... 111

LILIACE 2 .......... 118

Lilium Canadense....... 118

LABIATAE .......... 114 Lilium Philadelphicum.. 118

Lactuca Canadensis..... 111 Lily, Red........... 118

Ladies' Tresses........ 118 Lily, Yellow.......... 118

Ladies' Tresses, Slender.. 118 Limnanthemum lacuno-

Lady's Slipper, Showy... 118 sum ............ 113

Lady's Slipper, Stemless. 118 Linaria Canadensis...... 114

Lady's Slipper, Yellow... 118 Linaria vulgaris........ 114

Lady's Thumb......... 115 Lindera Benzoin........ 116

Larch ............ 117 Linnaea borealis....... 110

Larix Americana...... 117 Lion's Foot.......... 111

LAURACE $\$$........ 116 Liparis Loeselii........ 118

Laurel, Mountain....... 112 Live-For-Ever ........ 108

Laurel, Pale......... 112 Liver-Leaf .......... 103

Laurel, Sheep........ 112 Lobelia cardinalis...... 112

Leather-Leaf ......... 112 Lobelia Dortmanna..... 112

Leather-wood ........ 116 Lobelia inflata........ 112

Lechea maritima....... 105 Lobelia spicata........ 112

Lechea minor......... 105 Lobelia, Spiked........ 112

LEGUMINOSE ....... 107 Lobelia, Water........ 112

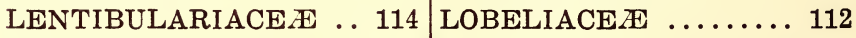

Leontondon autumnalis.. 111 Locust ............ 107

Leonurus cardiaca...... 115 Lonicera ciliata........ 110

Lepidium Virginicum.... 104 Loosestrife, Four-leaved.. 113

Lespedeza capitata...... 107 Loosestrife, Fringed..... 113

Lespedeza polystachya... 107 Loosestrife, Purple...... 109 
Loosestrife, Swamp..... 109 Loosestrife, Wing-angled. 109 Lupine, Wild......... 107 Lupinus, perennis....... 107 Lychnis Githago........ 105 Lycopus sinuatus....... 115 Lycopus Virginicus...... 115 Lysimachia quadrifolia... 113 Lysimachia stricta...... 113

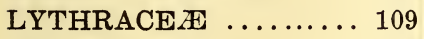
Lythrum alatum........ 109 Lythrum Salicaria...... 109

Mianthemum Canadense.. 118 Mallow, Common....... 106 Mallow, High......... 106 Malva rotundifotia...... 106 Malva sylvestris........ 106 MALVACE $\circledast$......... 106

Maple, Mountain....... 106

Maple, Red.......... 106

Maple, Striped........ 106

Maple, Sugar.......... 106

Maple, White......... 106

Marsh Marigold........ 104

Mayflower ........... 112

May-weed ............ 111

Meadow-Beauty ........ 109

Meadow-Rue, Tall...... 103
Meadow-Sweet ....... 107

Medeola Virginiana..... 118 Medic, Toothed......... 107 Medicago denticulata.... 107 Melampyrum America-.... num ............. 114 MELASTOMACEX .... 109 Melilot, White........ 107 Melilotus alba......... 107 Mentha Canadensis..... 114 Mentha piperita........ 115 Mentha viridis......... 114 Menyanthes trifoliata.... 113 Mignonette, Cut-leaved... 104 Mikania scandens....... 111 Milkweed, Common...... 113 Milkweed, Poke......... 113 Milkweed, Purple........ 113 Milkweed, Swamp...... 113 Milkwort, Common...... 107 Mimulus ringens........ 114 Mint, Mountain........ 115 Mint, Wild........... 114 Mitchella repens........ 110 Mitre-wort, False....... 108 Moehringia laterifolia.... 105 Monarda didyma....... 115 Monarda fistulosa....... 115 Moneses grandiflora..... 113 Monkey Flower......... 114 
Monotropa hypopitis.... 113 Monotropa uniflora...... 113 Motherwort, Common.... 115 Mountain-Ash ......... 108 Mullein, Common....... 114 Mullein, Moth......... 114 Mustard, Black......... 104 Mustard, Hedge......... 104 Myrica asplenifolia...... 116 Myrica cerifera....... 116 Myrica, Gale......... 116 MYRICACE $\ldots \ldots \ldots \ldots 116$

NAIADACE $\ldots \ldots \ldots \ldots .119$ Nasturtium Armoracia... 104 Nemopanthes fascicularis 106 Nepeta Cataria........ 115 Nepeta Glechoma....... 115

Nettle, Hemp......... 115

New-Jersey-Tea ....... 106 Nightshade ........... 114 Nightshade, Enchanter's. 109 Nine-Bark ........... 108 Nuphar Advena......... 104 NYMPH玉ACE $\ldots . . .104$ Nymphaea odorata...... 104 Nyssa sylvatica........ 110

Oak, Red........... 116
Oak, Scarlet......... 117 Oak, Scrub.......... 117 Oak, Scrub Chestnut.... 117 Oak, White.......... 116 Oak, Yellow-barked..... 117 Enothera biennis....... 109 Enothera chrysantha... 109 Enothera cruciata...... 109 Enothera fruticosa..... 109 Enothera pumila...... 109 OLEACE $\ldots$.......... 113 ONAGRACE $\nexists 2 \ldots \ldots \ldots 109$ Orange-grass ........ 106 ORCHIDACE ....... 117

Orchis, Fen......... 118 Orchis, Green......... 117 Orchis, Large Purple Fringed .......... 118 Orchis, Large Roundleaved ............ 118 Orchis, Northern White.. 117 Orchis, Ragged Fringed.. 117 Orchis, Rein.......... 117 Orchis, Small Green..... 118 Orchis, Small Purple

Fringed .......... 118 Orchis, White Fringed... 117 OROBANCHACEAE .... 114 Ostrya Virginica....... 116 Oswego Tea........... 115 
Oxalis Acetosella....... 106

Oxalis corniculata...... 106

Oxalis stricta......... 106

PAPAVERACE $\Phi$...... 104

Parsnip, Common....... 109

Parsnip, Cow.......... 109

Parsnip, Early Meadow.. 109

Parsnip, Meadow....... 109

Parsnip, Water........ 109

Partridge-berry ....... 110

Pastinaca sativa........ 109

Pearlwort ............. 105

Pedicularis Canadensis... 114

Pennyroyal, American... 115

Pennywort, Water....... 109

Penthorum sedoides..... 109

Pentstemon laevigatus... 114

Pepper, Mild Water...... 116

Peppergrass .......... 104

Peppermint .......... 115

Pepperidge ......... 110

Pepper-root ........... 104

Petasites palmata....... 111

Phlox subulata.......... 113

Physalis Virginiana..... 114

Physocarpus opulifolius.. 108

Physostegia Virginiana... 115

Phytolacca decandra..... 115
PHYTOLACCACE $¥$..... 115

Picea nigra........... 117

Pickerel-weed ......... 119

Pig-nut . . . . . . . . . 116

Pig-weed ........... 115

Pine, Pitch........... 117

Pine, Red........... 117

Pine, White.......... 117

Pine-sap ............. 113

Pink, Moss............ 113

Pinus resinosa......... 117

Pinus rigida........... 117

Pinus strobus........... 117

Pinweed ............. 105

Pipewort ............ 119

Pipsissewa ........... 112

Pitcher-Plant ......... 104

PLANTAGINACEZE .... 115

Plantago lanceolata...... 115

Plantago major......... 115

Plantain ............. 115

PLATANACE $A$....... 116

Platanus occidentalis.... 116

Pogonia affinis......... 117

Pogonia ophioglossoides.. 117

Poison-Ivy ........... 107

Pokeweed ............ 115

POLEMONIACE E ...... 113

POLYGALACE $\nexists E$....... 107

Polygala, Fringed...... 107 
Polygala paucifolia..... 107 Polygala polygama...... 107 Polygala sanguinea...... 107 POLYGONACEA ....... 115 Polygonatum biflorum... 118 Polygonum amphibium... 115 Polygonum arifolium.... 115 Polygonum articulatum.. 115 Polygonum aviculare..... 115 Polygonum dumetorum... 116 Polygonum hydropiperoides ............... 116 Polygonum Pennsylvanicum ............... 115

Polygonum Persicaria.... 115 Polygonum sagittatum... 115 Polygonum scandens..... 116 Pondweed ............ 119 Pontederia cordata....... 119 PONTEDERIACE $A$.... 119 Poplar, White........ 117 Populus alba........... 117

Populus balsamifera..... 117 Populus dilatata....... 117 Populus grandidentata... 117 Populus tremuloides..... 117 Portulaca oleracea...... 105 PORTULACACE $\ldots$..... 105 Potamogeton heterophyllus ............... 119
Potentilla argentea..... 108 Potentilla Canadensis.... 108 Potentilla Norvegica..... 108 Praenanthes serpentaria.. 111 PRIMULACE $\approx$........ 113 Primrose, Common Evening .............. 109 Primrose, Small Evening. 109 Prunus Pennsylvanica... 107 Prunus serotina........ 107 Prunus Virginiana...... 107 Purslane ............. 105 Pycnanthemum lanceolatum .............. 115

Pyrus Americana....... 108 Pyrus arbutifolia....... 108 Pyrus melanocarpa...... 108 Pyrus sambucifolia...... 108 Pyrola, One-flowered..... 113 Pyrola chlorantha...... 113 Pyrola elliptica......... 113 Pyrola rotundifolia...... 113 Pyrola secunda........ 113

Quercus alba.......... 116 Quercus coccinea........ 117 Quercus ilicifolia........ 117 Quercus prinoides....... 117 Quercus rubra......... 116 Quercus tinctoria....... 117 
Radish, wild......... 104

Ragwort, Golden........ 111

RANUNCULACE E .... 103

Ranunculus abortivus.... 103

Ranunculus acris....... 103

Ranunculus bulbosus..... 103

Ranunculus Flammula... 103

Ranunculus multifidus... 103

Ranunculus Pennsylvani-

cus ................. 104

Ranunculus repens...... 104

Ranunculus reptans..... 103

Ranunculus sceleratus.... 104

Ranunculus septentriona-

lis ................. 104

Raphanus Raphanistrum. 104

Raspberry, Black...... 108

Raspberry, Dwarf....... 108

Raspberry, Purple-Flower-

ing $\ldots \ldots \ldots \ldots \ldots \ldots 107$

Raspberry, Wild....... 108

Rattlesnake-Weed ...... 111

Rattlesnake-Plantain .... 118

Rattlesnake-Plantain, Les-

ser .............. 118

RESEDACE $A$........ 104

Reseda lutea.......... 104

RHAMMACE $A$....... 106

Rhamnus alnifolia...... 106

Rhexia Virginica....... 109
Rhododendron nudiflorum 112

Rhododendron Rhodora.. 113

Rhodora, Leafless....... 113

Rhus copallina........ 107

Rhus glabra.......... 106

Rhus Toxicodendron.... 107

Rhus typhina......... 106

Rhus venenata......... 107

Rib-grass ............ 115

Ribes Cynosbati....... 108

Ribes floridum......... 108

Ribes prostratum....... 108

Robinia Pseudacacia.... 107

Robin's Plantain....... 110

Rock-Rose .......... 105

Roman Wormwood...... 111

Rosa lucida........... 108

Rosa rubiginosa........ 108

ROSACE $\ldots$.......... 107

Rose ............. 108

RUBIACEAE ......... 110

Rubus Canadensis....... 108

Rubus hispidus........ 108

Rubus occidentalis...... 108

Rubus odoratus......... 108

Rubus strigosus......... 108

Rubus triflorus........ 108

Rubus villosus......... 108

Rudbeckia hirta....... 111

Rumex Acetosella....... 115 
Rumex crispus......... 115

Rumex obtusifolius..... 115

Sagina procumbens..... 105

Sagittaria latifolia...... 119

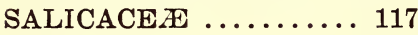

Salix alba............ 117

Salix cordata.......... 117

Salix discolor........... 117

Salix humilis........... 117

Sambucus Canadensis.... 110

Sambucus racemosa..... 110

Sandwort, Blunt-leaved.. 105

Sandwort, Thyme-leaved. 105

Sanguinaria Canadensis.. 104

Sanicula Canadensis..... 109

Sanicula Marylandica.... 109

SANTALACEAE ....... 116

SAPINDACE $A$....... 106

Saponaria officinalis..... 105

Sarracenia purpurea..... 104

SARRACENIACEE .... 104

Sarsaparilla, Wild...... 110

Sassafras ........... 116

Sassafras officinale...... 116

Saxifraga Pennsylvanica. 108

Saxifraga Dirginiensis... 108

SAXIFRAGACE王 ..... 108

Saxifrage, Golden....... 108
Saxifrage, Rock....... 108

Saxifrage, Swamp...... 108

Scutellaria galericulata.. 115

Scutellaria laterifolia.... 115

Scrophularia nodosa..... 114

SCROPHULARIACEÆ .. 114

Sedum acre........... 108

Sedum telephium....... 108

Senecio aureus.......... 111

Senna, Wild.......... 107

Sericocarpus solidagineus 112

Shad-bush .......... 108

Sheep-berry ......... 110

Shin-leaf ........... 113

Shepherd's Purse....... 104

Sicyos angulatus........ 109

Silene antirrhina....... 105

Silene Cucubalus........ 105

Silene dichotoma....... 105

Silene noctiflora........ 105

Silver-rod .......... 112

Sisymbrium officinale.... 104

Sisyrinchium anceps..... 118

Sisyrinchium angustifo-

lium .............. 118

Sium cicutaefolium..... 109

Skull-cap, Common...... 115

Skull-cap, Mad-Dog..... 115

Skunk-Cabbage ....... 119

Smilacina racemosa..... 118 
Smilacina stellata...... $118 \mid$ Sonchus oleraceus....... 111

Smilacina trifolia....... 118

Smilax herbacea....... 118

Smilax rotundifolia...... 118

Snakeroot, Black...... 109

Snakeroot, White...... 111

Snowberry, Creeping..... 112

SOLANACEAE ......... 114

Solanum dulcamara..... 114

Solidago altissima...... 112

Solidago arguta........ 112

Solidago bicolor........ 112

Solidago caesia......... 112

Solidago Canadensis..... 112

Solidago juncea......... 112

Solidago lanceolata..... 112

Solidago latifolia....... 112

Solidago nemoralis...... 112

Solidago odorata........ 112

Solidago patula......... 112

Solidago puberula....... 112

Solidago rigida........ 112

Solidago rugosa......... 112

Solidago serotina....... 112

Solidago stricta........ 112

Solomon's Seal, Common. 118

Solomon's Seal, Star-flowered

Solomon's Seal, Threeleaved ............ 118

Sorrel ............ 115

Sour-Gum .......... 110

Sparganium simplex.... 119

Spearmint .......... 114

Spearwort ........... 103

Speedwell, Common..... 114

Speedwell, Thyme-leaved. 114

Spergula arvensis....... 105

Spice-bush .......... 116

Spikenard .......... 110

Spikenard, False....... 118

Spiraea salicifolia...... 107

Spiraea tomentosa...... 107

Spiranthes cernua...... 118

Spiranthes gracilis..... 118

Spiranthes praecox...... 118

Spruce, Black......... 117

Spurge, Common....... 116

Spurge, Cypress........ 116

Spurrey, Corn......... 105

Spurrey, Sand......... 105

Starflower ........... 113

Starwort, Water....... 109

Steeple-Bush ......... 107

Steironema ciliatum..... 113

Stellaria borealis....... 105

Stellaria longifolia...... 105

Stellaria media........ 105

Stitchwort, Long-leaved. . 105 
Stitchwort, Northern.... 105 Sticktight .......... 111 Strawberry, Field....... 108 Strawberry, Wood....... 108 St. Johnswort......... 105 St. Johnswort, Marsh.... 106 Stork's-bill, Hemlock..... 106 streptopus roseus....... 118 Sumach, Dwarf........ 106 Sumach, Poison........ 106 Sumach, Smooth....... 106 Sumach, Staghorn...... 106 Sundew, Round-leaved... 109 Sundrops ........... 109

Sunflower, Wild........ 111 Sweetbrier ........... 108 Sweet-Flag ........... 119 Symphytum officinale.... 113 Symplocarpus foetidus... 119

Tansy ............... 111

Tanacetum vulgare..... 111 Taraxacum erythrospermum ............. 111

Taraxacum officinale..... 111 Tare ............. 107 Taxus Canadensis....... 117 Tear-Thumb ......... 115 Tear-Thumb, Halberd-
Thalictrum polygamum.. 103

Thaspium aureum...... 109 Thimble-weed .......... 103

Thistle, Canada........ 111

Thistle, Common....... 111

Thistle, Sow.......... 111

Thoroughwort ....... 111

THYMELEACE $\nexists$...... 115

Tiarella cordifolia...... 108

Tick-Trefoil ........... 107

Tilia Americana....... 106

TILIACE $\ldots \ldots \ldots \ldots . . . .106$

Tobacco, Indian....... 112

Toad-flax, Bastard...... 116

Toad-flax, Blue......... 114

Toothwort ............ 104

Trichostema dichotomum 115

Trientalis Americana.... 113

Trifolium agrarium..... 107

Trifolium arvense...... 107

Trifolium hybridum..... 107

Trifolium pratense...... 107

Trifolium procumbens... 107

Trifolium repens........ 107

Trillium cernuum........ 119

Trillium erectum........ 118

Trillium erythrocarpum.. 119

Trillium, Nodding...... 119

Trillium, Painted....... 119

115 Tsuga Canadensis....... 117 
Turnip ........... 104

Turtle-head .......... 114

Twin-flower ......... 110

Twisted-stalk ........ 118

Typha latifolia........ 119

TYPHACE $A$........ 119

Ulmus Americana...... 116

UMBELLIFER $Æ$. . . . . 109

URTICACE $\nexists \ldots \ldots \ldots .116$

Utricularia vulgaris..... 114

Uvularia perfoliata..... 118

Uvularia sessilifolia..... 118

Vaccinium corymbosum. . 112

Vaccinium macrocarpon.. 112

Vaccinium Oxycoccus.... 112

Vaccinium Pennsylvanicum .............. 112

Vaccinium vacillans..... 112

Velvet-leaf ........... 106

Veratrum viride........ 119

Verbascum Blattaria..... 114

Verbascum Thapsus..... 114

Verbena hastata........ 114

Verbena urticaefolia..... 114

VERBENACE $A$....... 114

Veronica scutellata..... 114
Veronica serpyllifolia.... 114

Vervain, Blue.......... 114

Vervain, White........ 114

Vetch ............. 107

Viburnum acerifolium.... 110

Viburnum cassinoides.... 110

Viburnum dentatum..... 110

Viburnum lantanoides.... 110

Viburnum Lentago..... 110

Viburnum nudum....... 110

Viburnum Opulus....... 110

Viburnum, Maple-leaved.. 110

Vicia Cracca.......... 107

Vicia sativa........... 107

Viola blanda.......... 105

Viola canina........... 105

Viola cucullata......... 105

Viola lanceolata......... 105

Viola palmata.......... 105

Viola palustriformis..... 105

Viola primulaefolia..... 105

Viola pubescens......... 105

Viola rotundifolia....... 105

Viola sagittata........ 105

VIOLACE $\ldots \ldots \ldots \ldots 105$

Violet, Arrow-leaved.... 105

Violet, Common Blue.... 105

Violet, Dog.......... 105

Violet, Downy Yellow.... 105

Violet, Lance-leaved..... 105 
Violet, Primrose-leaved.. 105 Willow, Prairie........ 117

Violet, Round-leaved.... 105 Willow, White......... 117

Violet, Sweet White..... 105 Willow-Herb, Small..... 109

Virgin's-Bower ........ 104 Wind-Flower ......... 103

VITACEA .......... 106 Winterberry, Smooth... 106

Vitis labrusca......... 106 Witch-Hazel ........ 108

Vitis riparia.......... 106 Withe-rod .......... 110

Woodbine ........... 106

Wood-Sorrel .......... 106

Wake-Robin ......... 118 Wood-Sorrel, Yellow.... 106

Water-Crowfoot, Yellow.. 103

Water-Lily ........... 104

Water-Plantain ........ 119

Yarrow ............. 111

Water-Shield .......... 104

Willow, Glaucous....... 117

Willow, Heart-leaved.... 117 Zizia aurea.......... 109 
THE HERMIT THRUSH.

The Pine Plains darkled,

The river sparkled,

Kearsarge soared purple dim;

From hazel bush

A hermit thrush

Poured forth his evening hymn.

“ $O$, souls in prison pent,

Follow the way $\mathrm{He}$ went!

Ye shall be free-be free!

Lift up your fearful eyes!

Love rules beyond the skies.

Blessed forever be!"

The pine trees solemn,

Column on column,

Upheld the rose-flecked blue.

$O$, bird that pain dispels,

Again chime thy silver bells,

Angel and poet true!

The sunset's crimson

Dissolves and dims on

The mount turned amethyst.

Falls then a holy hush;

List now the spirit thrush?

E'en Heaven's gate those strains cannot resist!

"Let not your heart despair;

Comfort comes everywhere.

Mercy will stay.

Peace to the burden-bearers!

They shall be treasure-sharers.

Earth fades today; Heaven lasts alway!"

DeCember 17, 1901. 




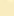



(9)

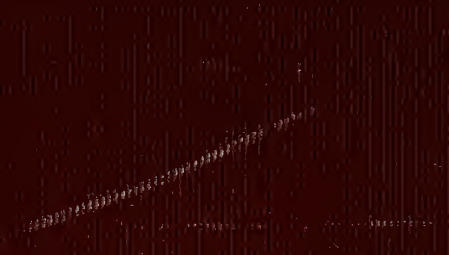

$s$ 